\title{
Respiratory diseases and allergy in farmers working with livestock: a EAACI position paper
}

\author{
T. Sigsgaard ${ }^{1 *} \mathbb{0}$, I. Basinas², G. Doekes ${ }^{3}$, F. de Blay ${ }^{4}$, I. Folletti ${ }^{5}$, D. Heederik ${ }^{3}$, A. Lipinska-Ojrzanowska ${ }^{6}$, \\ D. Nowak ${ }^{7,8}$, M. Olivieri ${ }^{9}$, S. Quirce ${ }^{10}$, M. Raulf ${ }^{11}$, J. Sastre ${ }^{12}$, V. Schlünssen ${ }^{1}$, J. Walusiak-Skorupa ${ }^{6}$ and A. Siracusa ${ }^{13}$
}

\begin{abstract}
Farmers constitute a large professional group worldwide. In developed countries farms tend to become larger, with a concentration of farm operations. Animal farming has been associated with negative respiratory effects such as work-related asthma and rhinitis. However, being born and raised or working on a farm reduces the risk of atopic asthma and rhinitis later in life. A risk of chronic bronchitis and bronchial obstruction/COPD has been reported in confinement buildings and livestock farmers. This position paper reviews the literature linking exposure information to intensive animal farming and the risk of work-related respiratory diseases and focuses on prevention. Animal farming is associated with exposure to organic dust containing allergens and microbial matter including alive microorganisms and viruses, endotoxins and other factors like irritant gases such as ammonia and disinfectants. These exposures have been identified as specific agents/risk factors of asthma, rhinitis, chronic bronchitis, COPD and reduced FEV ${ }_{1}$. Published studies on dust and endotoxin exposure in livestock farmers do not show a downward trend in exposure over the last 30 years, suggesting that the workforce in these industries is still overexposed and at risk of developing respiratory disease. In cases of occupational asthma and rhinitis, avoidance of further exposure to causal agents is recommended, but it may not be obtainable in agriculture, mainly due to socio-economic considerations. Hence, there is an urgent need for focus on farming exposure in order to protect farmers and others at work in these and related industries from developing respiratory diseases and allergy.
\end{abstract}

Keywords: Agriculture, Asthma, Farm animals, Rhinitis, Work-related

\section{Background}

Although their numbers have declined considerably in most developed countries, farm owners and farm workers still constitute a large professional group [1]. The last decades showed a strong tendency towards specialization and concentration, leading to fewer but bigger farms. Farming practices are changing with large-scale enterprises gradually replacing smaller scale traditional family farms $[2,3]$.

\footnotetext{
*Correspondence: ts@ph.au.dk

${ }^{1}$ Department of Environment Occupation \& Health, Dept of Public Health, Danish Ramazzini Centre, Aarhus University, Bartholins Allé 2, Build. 1260, 8000 Aarhus C, Denmark

Full list of author information is available at the end of the article
}

Farm workers are exposed to airborne dust, microbial agents, and gases, particularly in livestock farming in closed confinement buildings. The increased risks of respiratory disease, including work-related (WR) asthma, rhinitis, and enhanced lung-function decline compatible with chronic obstructive pulmonary disease (COPD), have been well-recognized and summarized in the 80s and 90s [4], and confirmed in more recent reviews. Although general recommendations to lower exposure levels have been published, there is little evidence that these have been effectively implemented, and the risks of respiratory health problems in farmers may have remained high [5-8].

Given the ongoing changes in agricultural practice, it is worthwhile to assess their impact on respiratory health of farm workers. On the other hand, farm life has since 
the late 90 s become widely known as protective against type I allergic sensitization and disease-particularly for children living on livestock farms, while protection seemingly also extends into adulthood [9-11]. The widespread recognition of this 'anti-atopy protective' effect might however also have led to underestimation or disregard of farm WR respiratory health risks.

An EAACI task force therefore produced a systematic update of evidence from the last two decades with regard to:

- prevalence and incidence of asthma/wheezing, rhinitis/rhinoconjunctivitis, atopic sensitization, bronchitis, and COPD in livestock farmers.

- clinical features, pathogenic mechanisms and diagnosis of farm work-related respiratory disease.

- the 'anti-allergy protection paradox': that living on a farm may protect against, while farm work would enhance the risk of asthma and rhinitis.

- exposure: levels and determinants, and protective measures to lower exposure.

Another major occupational risk of farm work-associated microbial and dust exposures is hypersensitivity pneumonitis (HP) - a potentially serious lung disease caused by high microbial exposures, strong humoral IgG sensitization against their-mainly fungal-allergens, and immune complex-mediated inflammation. Since HP has been extensively reviewed in another recent EAACI position paper [12], it is here just mentioned, but not further discussed.

Schenker et al. [4] have previously comprehensively reviewed the relevant published literature prior to the year 2000. For the present study extensive searches were therefore performed in literature from the last 18 years, with a primary focus on studies among farmers working with large animals/livestock (dairy and beef cattle, pigs, sheep, horses, poultry), and on respiratory symptoms and diseases and pulmonary function tests (wheezing, cough, asthma, rhinitis/rhinoconjunctivitis, chronic bronchitis, COPD and lower airway obstruction).

Results from three MEDLINE searches were combined (details in Appendix S1): 177 studies, 73 of which considered relevant to this document, were identified covering the years from 2000 through June 30, 2018. From the reference lists of relevant papers published since 2012 another 4 primary papers were added.

\section{Main text Epidemiology}

Table 1 gives an overview of incidence and prevalence studies in livestock farmers, arranged by respiratory health outcome.

\section{Asthma and wheeze}

New onset asthma in farmers was reported in the Danish study of young farmers (SUS) [8], which found that during the first years after farming school the risk was significantly increased for work with swine [OR $(95 \% \mathrm{cfi})=3.4$ $(1.6-7.0)]$ and dairy cattle $[\mathrm{OR}=2.5(1.1-5.3)]$. The risk was strongly associated with non-specific bronchial hyperresponsiveness (NSBHR) at baseline, but not with atopy, while a farm childhood was protective $[\mathrm{OR}=0.5$ (0.3-0.98)].

The European Community Respiratory Health Survey (ECRHS) follow up study found that new onset asthma was non-significantly associated with agricultural work in general $[\mathrm{OR}=1.9(0.7-5.2)]$, but did not discriminate between types of farm exposures [13].

In a range of other, cross-sectional studies, wheeze and asthma were associated with exposure to swine, dairy cattle, horse and sheep, but also with more specific exposures like manure (Table 1 ).

\section{Rhinoconjunctivitis}

Various cross-sectional studies have confirmed the previously well-established associations between nasal irritation and high dust exposures in farming. Increased ORs were reported for work with swine $[\mathrm{OR}=1.5(1.2-1.9)$ [14], work with horses and in horse stables [rhinitis $\mathrm{OR}=1.8(1.0-3.1)]$; conjunctivitis $[\mathrm{OD}=3.9(1.6-6.6)]$ [15], for 'highly exposed' horse barn workers $[\mathrm{OR}=3.5$ $(1.1-10.6)][16]$ and in sheep breeders $[\mathrm{OR}=3.2(2.1-$ 4.6)] [17].

Kronqvist et al. reported that rhino-conjunctivitis among farmers on the isle of Øland in Sweden was associated with dust mite sensitization, and that this sensitization was related to the time in farming, and thus work-related [18].

\section{Chronic bronchitis and COPD}

Chronic bronchitis (traditionally used to define COPD) has been statistically significantly associated with various dusty environments, including farms of different trades with point estimates for work with livestock of OR $1.9[19,20]$, dairy cattle 1.2 to 4.7 [21, 22]; swine 3.2 to $4.3[19,23]$ and horses 1.6 to 2.3 [24, 25]. Increased risks of COPD were reported for livestock farmers $[\mathrm{OR}=1.4(1.1-2.6)]$ [20]; non-smoking farmers working in confinement buildings $[\mathrm{OR}=6.6(1.1-40)][26]$ and traditional farming $[\mathrm{OR}=5.2$ $(1.7-16)]$ [27]. One study found associations with 3 different exposures (i) dairy cattle $[\mathrm{OR}=1.8(1.1-3)]$; (ii) swine [2.3(1.1-4.9)] and (iii) poultry [2.6 (1.0-4.1)] [28] (Table 2). Thus, most animal husbandry is related to an increased prevalence of chronic bronchitis as well as COPD, with the 


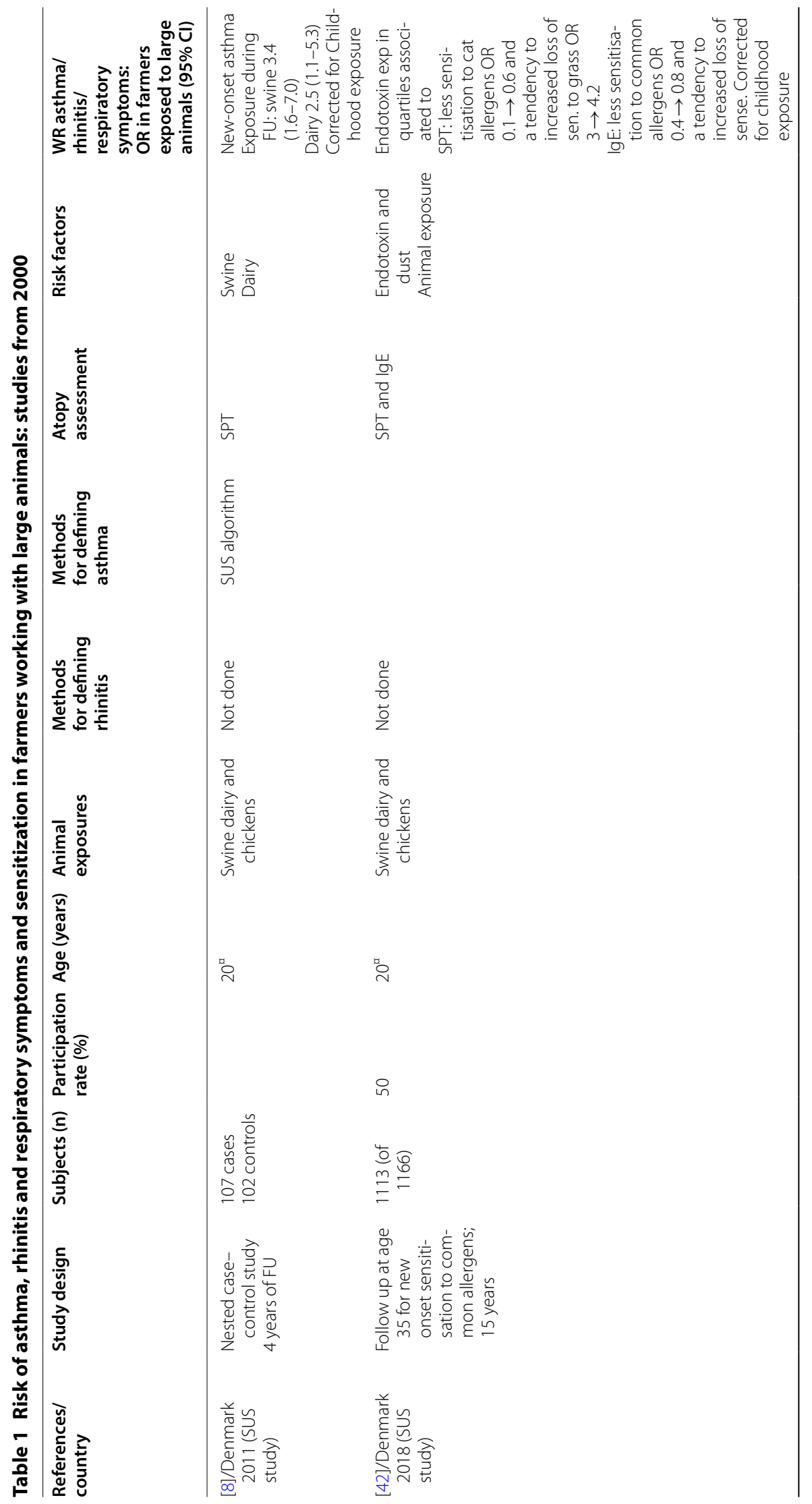




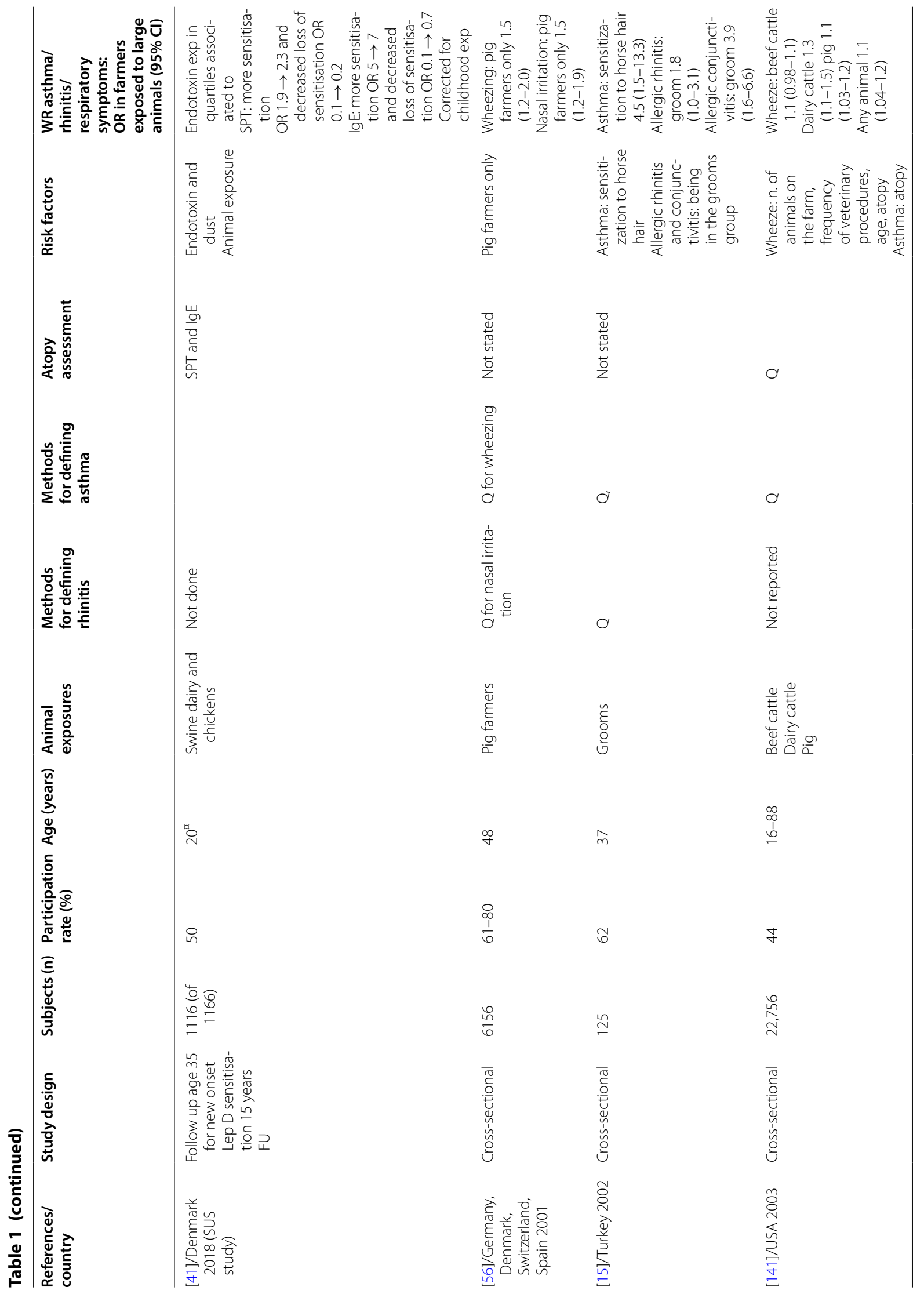




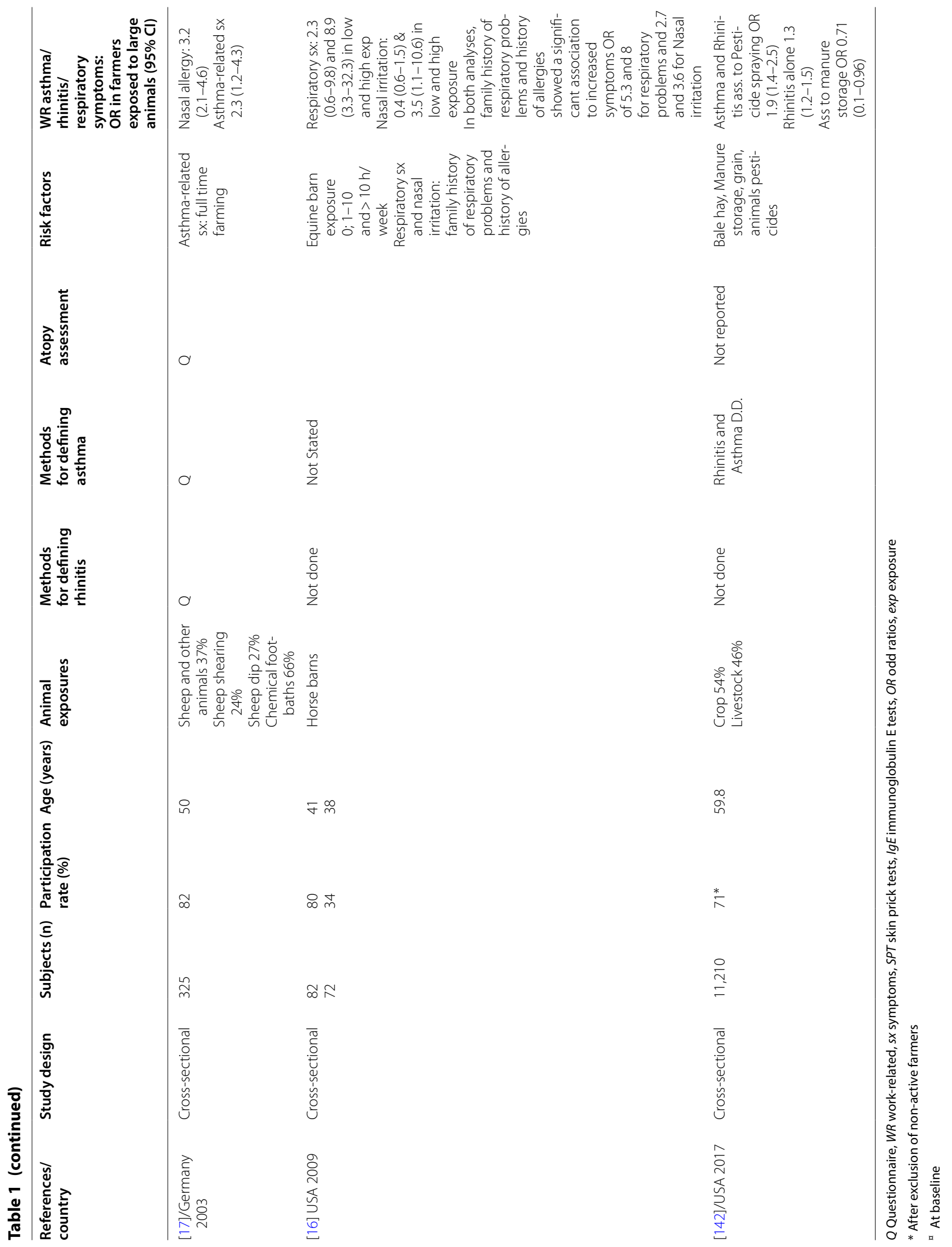


highest relative risk in non-smoking farmers and female farm-workers from Concentrated Animal Feeding Operations (CAFOs) [23].

\section{Lung function}

The few follow up studies on lung function development clearly indicate an increased risk of obstructive changes over time (Table 2). However, the effects are modest according to a recent review [29]. Non-smoking Danish farmers showed an accelerated loss of forced expiratory flow in the first second $\left(\mathrm{FEV}_{1}\right)$ of $53 \mathrm{ml}$ per year among swine-breeders compared to $36 \mathrm{ml}$ per year among dairy farmers [30]. Studies in France where the study population comprising of dairy farmers was followed for periods of 6 [31] and 12 years [32] showed an accelerated decline in Tiffeneau index $\left(\mathrm{FEV}_{1} / \mathrm{VC}\right)$ of 0.3 and $1.2 \%$ year $^{-1}$ in comparison to controls. In a reinvestigation of the French $12 \mathrm{yr}$ follow-up data an accelerated decline in $\mathrm{FEV}_{1} / \mathrm{FVC}$ was calculated of $-0.21 \pm 0.08 \%$ year $^{-1}$ among the dairy farmers and an accelerated decline in $\mathrm{FEV}_{1}$ of $-9.12 \pm 4.7 \mathrm{ml} \mathrm{year}^{-1}$ in the group handling animal feed [22].

One study additionally reported a significant interaction for COPD between traditional farming and smoking with ORs of 5.4 for traditional farm, 1.3 for smoking and 8.3 for the combination of smoking and working on a traditional farm [27].

At 15 year follow-up in the Danish SUS study, a farm work-associated accelerated decline was noted for $\mathrm{z}$-scores $\mathrm{FEV}_{1}\left(0.12\right.$ year $\left.^{-1}\right)$ and $\mathrm{FEV}_{1} / \mathrm{FVC}\left(0.15\right.$ year $\left.^{-1}\right)$. Furthermore NSBHR at baseline appeared to be a risk factor for decline in $\mathrm{FEV}_{1}$, but only in farmers without farm childhood. Interestingly, being raised on a farm was protective against a decline in $\mathrm{FEV}_{1}$ and $\mathrm{FEV}_{1} / \mathrm{FVC}$ during follow up [29].

Two cross-sectional studies have reported lung function in farmers with diverging results (Table 2). A smaller Canadian study in 375 swine farmers showed no differences in lung function between swine farmers and controls [33], whereas a greater more general study of 4735 Norwegian farmers found $\mathrm{FEV}_{1}$ significantly reduced among animal breeders compared to crop farmers [20].

In summary, the risk of obstructive lung function changes has remained high in farmers engaged with animals and animal feeding operations, or as an interaction between smoking and farm work exposures. However, the acceleration in lung function decline seems to be modest [34].

\section{Pathogenesis, clinical features, diagnosis, and protective effects}

\section{Pathogenic mechanisms}

Asthma and rhinitis in farmers may vary from IgE-mediated allergy to specific farm allergens, to
non-IgE-dependent innate immunity responses to microbial agents, or dust-, chemical-, or other irritant-induced airway reactivity [35].

Most reported specific type I allergies are to storage mite [20] and bovine allergens [39-42, 54], while IgE sensitization to horse allergens has been recognized as a growing problem in horse riders and horse stable workers [15, 36]. IgE to storage mites can be found in dairy farmers, and dust from their homes shows enhanced concentrations of storage mite allergens, e.g. A. siro, $L$. destructor and T. putrescentiae [37]; relations with storage mite sensitization and ensuing rhinitis and asthma are however not well-established. Dairy farmers are also exposed to bovine allergens and Bos $d 2$ is an important major allergen in cattle barns, also found in farm house dust [38-40].

However, there is a lack of population data to assess whether these high exposures to farm allergens are associated to WR rhinitis and asthma. Given the high exposure levels, the sensitization frequency among farmers is remarkably low-possibly as a result of the 'anti-atopy' protective effect of the farm environment, as discussed below. Interestingly, in the Danish follow-up study, new sensitization to storage mite ( $\mathrm{Lep} d$ ) was positively associated with farm work, whereas sensitization to common allergens tended to decrease at higher farm exposures [40-42].

Most work-related upper (URT) and lower respiratory tract (LRT) symptoms in farmers, however, are probably caused by non-IgE mediated, innate immunity responses to airborne agents of microbial origin, which are inhaled at high levels in livestock farming [43]. Many of the components of the bio-aerosols in stables are pathogenor microbial-associated molecular patterns (PAMPs/ MAMPs) that bind to specific receptor molecules and activate innate immunity pathways [44]. Inhaled PAMPs from bio-aerosols induce airway inflammation in healthy and asthmatic subjects and symptom exacerbations to a variable degree, likely depending on the burden of exposure and some polymorphisms in the endotoxin cell receptors and signal transduction molecules [44]. Airway inflammation starts in the case of endotoxin through the TLR4-pathway, peptidoglycan by TLR2-associated peptidoglycan recognition proteins (PGRPs), nucleotidebinding oligomerization domain (NODs) molecules and $\beta(1 \rightarrow 3)$-glucans (polymers of glucose produced in fungi, plants and some bacteria) may act through the $\beta$-glucan receptor, Dectin-1, expressed on macrophages and neutrophils (Fig. 1).

Most intensively studied are the pathogenic mechanisms of wheezing and asthma in pig farming, especially in swine confinement buildings, where high and chronic airborne PAMP exposures may not only lead to 


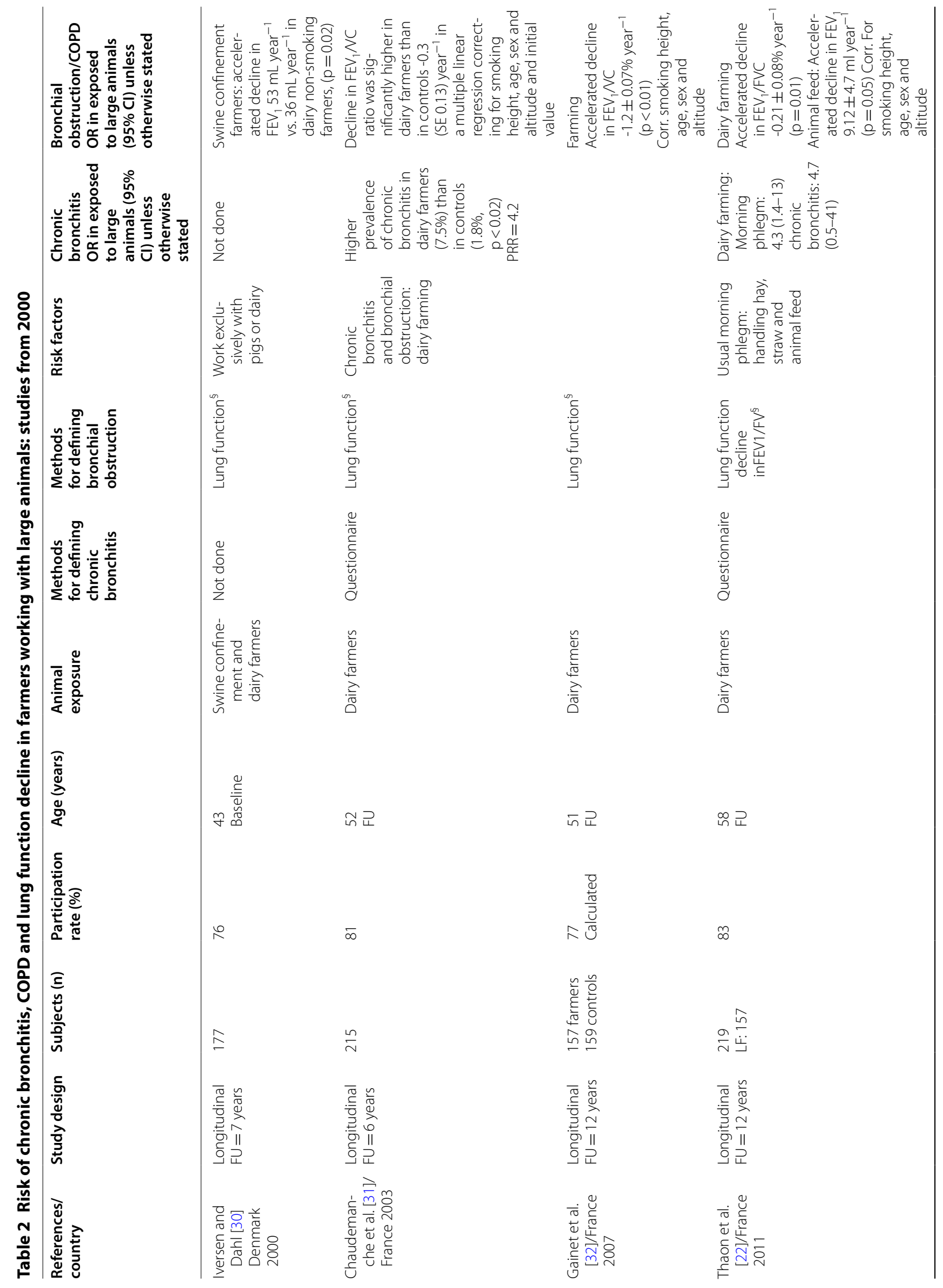




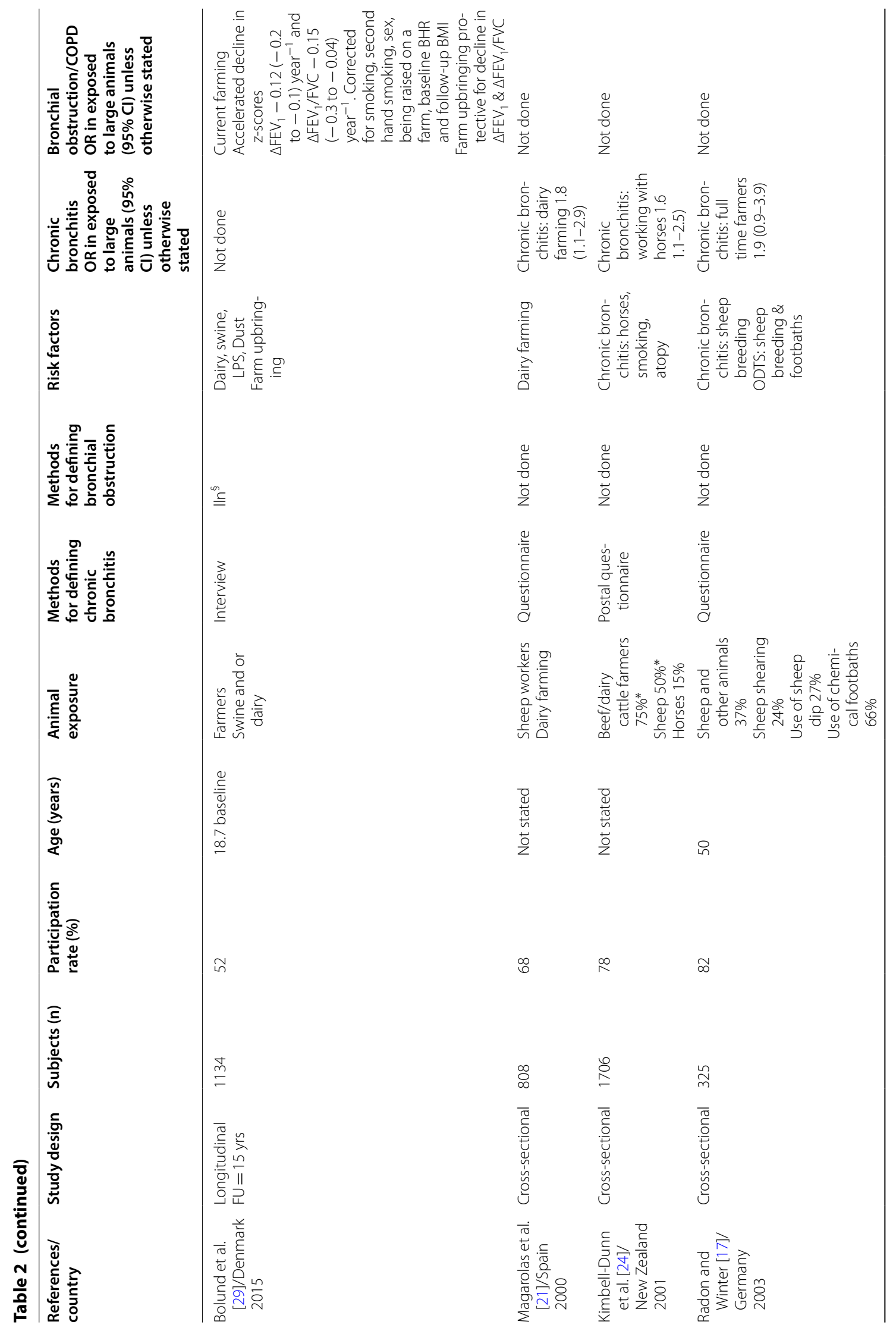




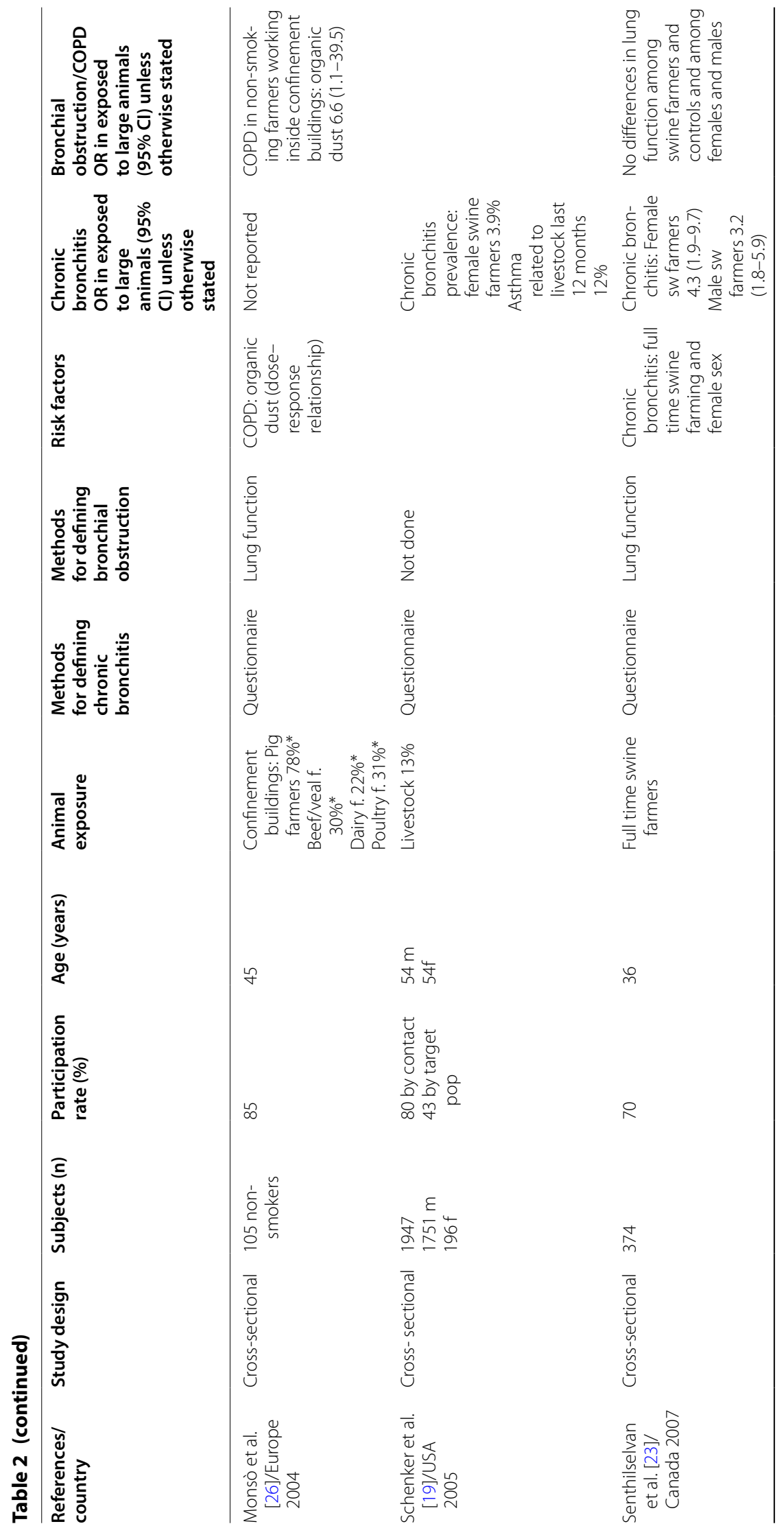




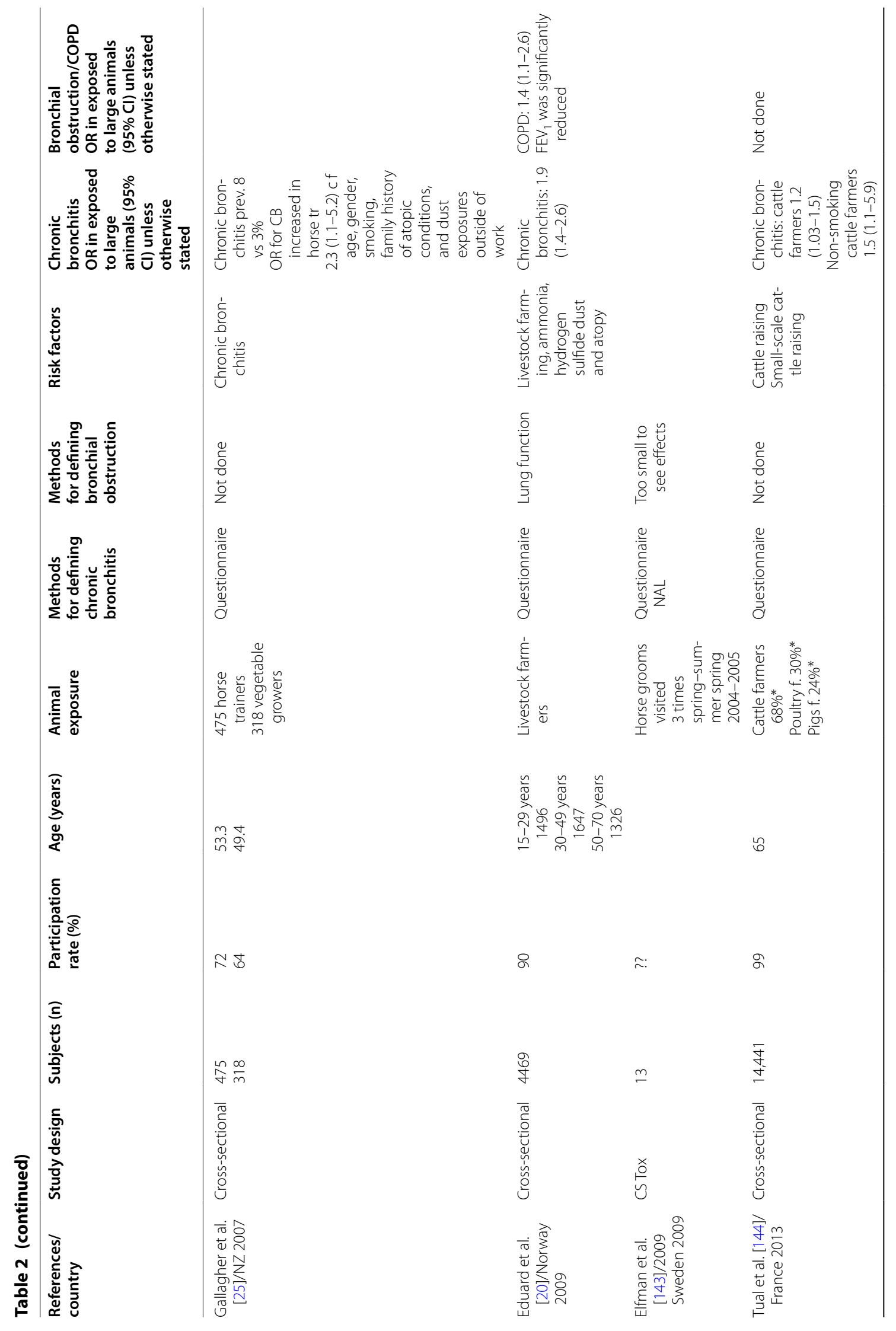




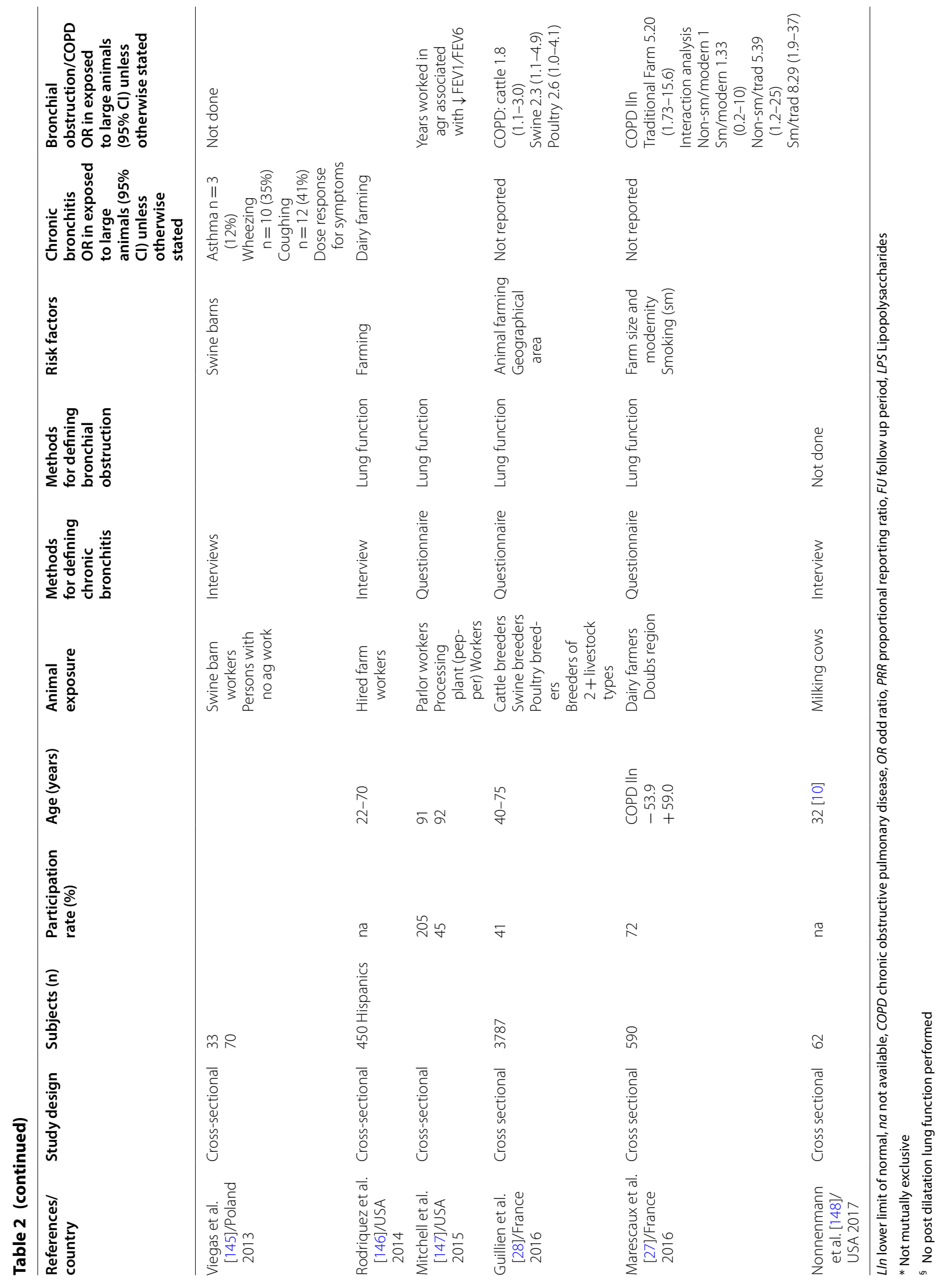


local airway and lung inflammation, but also to systemic effects as shown by increased levels of circulating serum cytokines TNF- $\alpha$, Il-6 and Il-1 $\beta$ [30, 45, 46] (Fig. 1). Symptoms are wheeze, coughing and other typical asthmatic symptoms and features like increased NSBHR [47-50]. In naïve subjects high exposures during a few hours in a pig stable may even lead to symptomatic systemic inflammation with increased body temperature, chills and malaise $[48,49]$. Interestingly repeated Organic Dust Toxic Syndrome (ODTS) is associated with a fivefold increase in chronic phlegm risk [51].

\section{Clinical features}

Farm work-related URT and LRT symptoms as such do not show typical features with which they might be distinguished from non-occupational cases. Asthma may have several phenotypes, such as IgE-mediated asthma characterized by high reversibility in airway obstruction [52] and non-atopic asthma with low reversibility, NSBHR and wheezing $[35,53]$. Nasal symptoms such as congestion, rhinorrhea and pruritus are common in farm workers across the different areas in agriculture [4, 54] including veterinarians [55]. Several cross-sectional studies report nasal irritation without mentioning other symptoms of rhinitis while others described rhinitis combined with conjunctivitis. Among 6156 randomly selected animal farmers in Denmark, Germany, Switzerland and Spain, the prevalence of nasal irritation was $22 \%$ for farmers working with cattle, 29\% for pig farmers, $21 \%$ for working with sheep and $22 \%$ for mixed farming [56].

The role of atopy-defined as positive skin prick or IgE tests to common allergens-is not always clear. In cases with specific type I allergy to farm allergens like storage mites or bovine allergens, sensitization to common allergens is one known risk factor [57, 58]. However, in a community based sample of farmers, no association was found between sensitization to cow dander and occupational symptoms [59]. In several studies in farmers and other agricultural workers the prevalence of common atopy was low (10-15\%) compared to contemporary population studies $(>25 \%)$, but atopics were at higher risk to develop URT- and LRT-symptoms, including nonIgE mediated airway inflammation induced by microbial agents [10]. In contrast, in Danish young farmers prevalence and incidence of asthmatic disease was independent of common atopy, while NSBHR at baseline was a risk predictor [8].

Repetitive farming exposure can result in chronic lung inflammatory disease with significant decline in lung function over time [29, 30, 32]. In a substantial fraction of workers there might also be a "chronic inflammatory adaptation response" as a significant attenuation of the initial, robust inflammatory response following repetitive exposure, of which the precise mechanism is not clear [60]. Such tolerance is however definitely not a general feature common to all farm workers exposed to high levels of microbial dusts [10].

\section{Diagnosis}

Diagnosis is complicated by the variety of etiologic agents and pathogenic mechanisms present in farming environments. Since the majority of cases may not be due to specific allergic sensitization to occupational allergens, negative results of skin prick or IgE tests may easily lead to a failure to identify farm-related causal factors. It is of crucial importance that the diagnostic anamnesis of a farm worker presenting with respiratory symptoms includes a careful inventory of work-related exposures that might induce or aggravate allergic symptoms. Practitioners must be well aware that neither atopic sensitization to common allergens, nor a lack of specific sensitization to farm allergens should be interpreted as negative evidence against farm exposures as primary or secondary causes of the farmer's respiratory ailment. Asthma diagnosis is performed according to the statement by an earlier position paper [61]. In the presence of work-related rhinitis or asthma, serial recordings of nasal symptoms and peak flow measurements can be performed. In some cases objective assessment using provocation challenges in the laboratory or at the workplace can be recommended for asthma and rhinitis [62].

Diagnostic tests for specific allergies are only helpful in the minority of patients with type I allergies to farmrelated antigens, e.g. in Finland where cow dander has been recognized as an important type I occupational allergen, since the majority of farmers with allergic rhinitis had a positive reaction to nasal challenge with cow dander [57]. Similarly, suspected type I allergy to storage mites or horse allergens may be tested with appropriate skin prick tests (SPTs) or IgE tests if available, but even in case of proven sensitization the link between exposure to the allergen and occurrence of symptoms must be confirmed by a careful anamnesis or by specific inhalation challenge (SIC) tests.

SICs with specific allergens can be conducted either with the suspected specific agent in the laboratory or at the subject's workplace [61]. These tests should be conducted only by specialized centers. SICs may be especially useful when a) alternative procedures have failed to identify with sufficient accuracy the diagnosis of occupational allergy; b) the patient is no longer exposed at work; or c) there is need to identify a particular agent/s; d) if an agent has not previously been recognized as a causal factor; and e) for medico-legal requirements.

There is no single diagnostic test available to confirm or exclude a diagnosis of disease caused by innate 

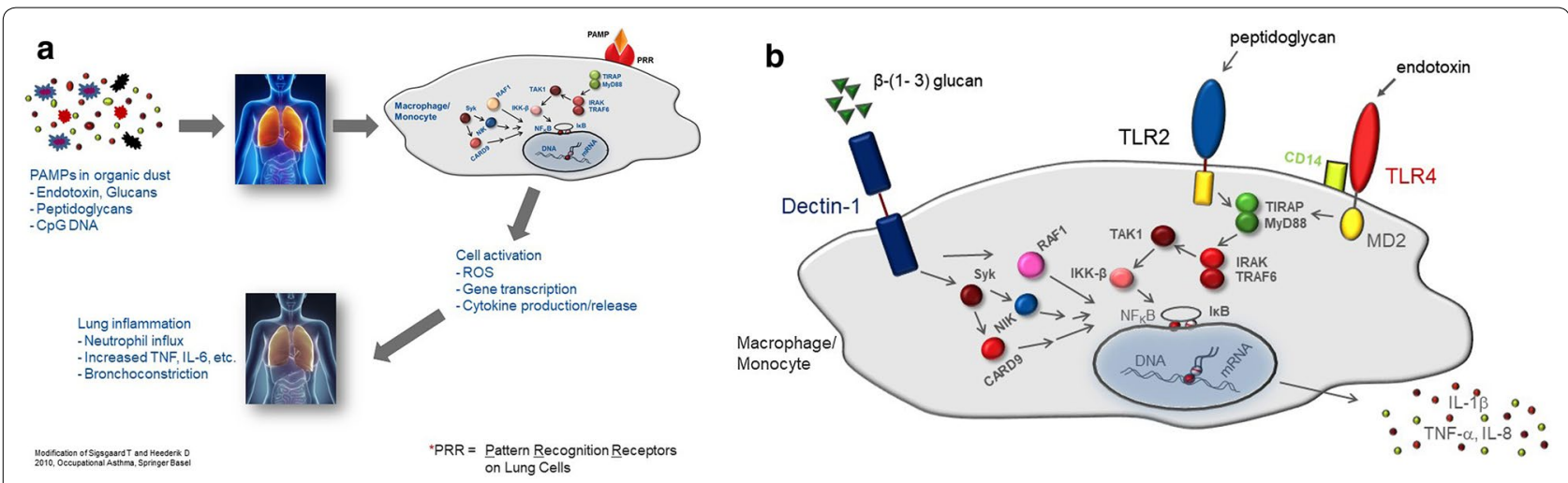

Fig. 1 Mechanism PAMP-induced innate immunity responses to microbial agents. Examples for PAMPs (activators of the innate immune system) Endotoxin (LPS) signaling through TLR4-pathway expression TLR4 LPS induced inflammatory response (e.g. RSV increased TLR4) although LPS causes inflammation in everyone, people with asthma tend to be more sensitive several proteins are involved in LPS-response. Peptidoglycan signaling by TLR2 and, PGRPs (peptidoglycan recognition proteins), and NODs (nucleotide-binding oligomerization domain molecules) $b(1 \rightarrow 3)$-glucans (polymers of glucose produced in fungi, plants and some bacteria) Dectin-1, expressed on macrophages and neutrophils, is the b-glucan receptor Dectin-1 may function as a T cell co-stimulatory molecule, suggesting that b-glucan stimulation may be a link between innate and adaptive immune response

immunity reactions to airborne PAMPs at the workplace. A controlled inhalation challenge test may be performed at the workplace, but the nature of innate immunity reactions implies that also naïve subjects may vigorously respond to such exposures. Hence, such challenges alone do not confirm a specific responsiveness to work-related exposure.

Nasal provocation tests can be performed also either in the laboratory under controlled conditions or at work under natural conditions to confirm the presence of occupational allergic rhinitis.

Nonspecific inhalation challenges-with e.g. histamine, methacholine, cold air or hypertonic saline-may be helpful in the diagnosis of asthma, as a positive reaction is a serious predictor of later onset asthma in young farmers [8]. In young farmers without a farm childhood, and thus relatively naïve to the farm environment, NSBHR was found to be associated with an increased decline in lung function over a 14 year follow up [29].

In general, the diagnosis of farm-related LRT and URT illness must primarily rely on a strong systematic anamnesis focusing on specific work tasks with high exposure. In some specific cases, such as in clusters of workforces with a sudden very high incidence of work-related symptoms, anamnesis should be supported by exposure measurements at the workplace, and monitoring of time and place when and where symptoms occur. Another issue to consider is, that endotoxin induced inflammation and NSBHR usually develop with a sub-acute pattern, i.e. not simultaneously with exposure, but most often start $4-8 \mathrm{~h}$ after exposure.

\section{Protection by the farm environment}

Chronic exposure to animal farm dusts may also attenuate inflammatory responses and even protect against type I allergies. Adaptation to high endotoxin exposure has been described already $>30-40$ years ago in cotton workers who showed the most vigorous responses after the weekend (hence called 'monday morning fever') or after a few weeks off-work, while after some days of exposure the acute inflammatory responses and symptoms became less severe [63, 64]. Similar effects have been found in experimental studies in which airway and systemic inflammation (measured as cytokines in nasal fluid and/or induced sputum, and in serum) and changes in NSBHR were compared between swine workers and healthy volunteers after exposure to swine barn dust $[47,65,66]$. Swine farmers had higher baseline levels of inflammatory markers, suggesting chronic airway inflammation, but responded less to acute exposures than naïve volunteers $[47,67]$. The mechanisms behind this apparent "adaptation" to high airborne organic dust exposures are not known $[68,69]$, but probably similar to those of the much better studied 'endotoxin tolerance' of innate immunity cells in studies of endotoxin exposure due to life-threatening systemic bacterial infection [70-72]. If such mechanisms indeed also are operative in farmers with chronic microbial exposures, it would explain why adverse health effects in some studies may appear to be less severe than expected based on their high exposure levels. Healthy worker selection (HWS) may also be involved [33, 73, 74], but its role may vary among populations in different countries and types of farming [75]. 
However, it would be a serious misunderstanding to conclude that farm workers after some time become tolerant. Although acute responses may be attenuated, there is overwhelming evidence of ongoing chronic airway inflammation and a more rapid decline of lung function in populations highly exposed to PAMPs [44].

The other 'beneficial' effect of exposure to the livestock farm environment is the lower risk of allergic (atopic) asthma and rhinitis among those born and raised on a farm. These findings, published for young farmers [76], school children in Alpine regions [77-80] and confirmed in studies from many other countries $[7,10,11$, 42, 81-94], revived nineteenth century knowledge that hay fever is rare in farmers [95]. A commonly accepted explanation holds that the developing immune system of farm children is primed towards a state of non-atopic responsiveness or immune tolerance for allergens [42, 77, $81,84,96]$, by chronic inhalation of farm dust containing pro-inflammatory "microbe-associated molecular patterns" (MAMPs) (see paragraph on mechanisms), and/or by frequent ingestion of unpasteurized milk that also may contain enhanced concentrations of such MAMPs and in addition other agents with immunoregulatory properties like prebiotics and various cytokines; according to these theories it would be the very early or even prenatal farm exposures that protect against type I allergies. These protective effects might be most pronounced for traditional small-scale farming, as in children studied in the original reports from Alpine regions [77, 78, 80]. Other evidence for such an association restricted to more 'old-fashioned' farming comes from the study by Stein et al. [90] in the USA, who compared atopy in children from Amish communities who adhere to strict traditional farm practices, with children from the more modern Hutterite families. Lower risks of type I sensitization and type I allergic disease have however also been found in several other populations of both children and adults who grew up in the last decades in relatively modern farms, as in The Netherlands, Sweden [97-101] and Denmark [11, 42, 88].

Since many farm workers also have been raised on a farm, it is hard to assess these effects separately. Table 3 summarizes studies on the prevalence of atopy and atopic disease in farmers and non-farmers, with farm childhood also taken into account. In many studies, a farm childhood appeared to confer a long-lasting protection into adulthood $[7,10,11,82,83,85-89,91-93$, 101-103], while some also reported evidence that current farm work may additionally protect against sensitization to common allergens and/or atopic illness [88, 89, $96,102,103]$. One longitudinal study found a lower risk of new pollen sensitization in young adulthood, especially in those with high animal stable dust and endotoxin exposures [42]. HWS bias seemed unlikely, since the frequencies of NSBHR and wheezing are higher or similar among the highly exposed workers, and protection in adulthood appeared to be mainly restricted to atopic sensitization. It especially pertained to hay fever, pollen sensitization [11, 42, 96, 101] and atopic asthma, while non-atopic wheezing and NSBHR are more prevalent at high farm dust exposures $[8,76,89,101,104]$. Thus, farm work-associated exposures may, in addition to a farm childhood, protect against persistence of, or newly originating atopic sensitization to pollen and possibly other common allergens $[10,11,101]$.

The widespread knowledge of the farm-associated low risk of atopy may easily lead to a common but incorrect belief that "the farm environment protects against asthma and rhinitis". As emphasized in this position paper, farm work remains a major risk factor for (mostly non-atopic) LRT and URT illness and the 'anti-atopy' effect is mainly a complicating factor in the diagnostic workup. A clear distinction between atopic and non-atopic respiratory disease is thus essential. Studies in both adults and children have found that high endotoxin exposure, although negatively associated with atopic asthma-defined as wheezing illness combined with atopic sensitization -, is positively associated with wheezing in the absence of atopy [89]. The meta-analysis of studies with objectively determined atopy markers-SPT or IgE positivityfound as most consistent finding protection by both a farm childhood and adult farm work against atopic sensitization, especially against pollen [42]. Most population studies however did not clearly distinguish between atopic sensitization and associated illness. Hence, the often-reported protection against "(atopic) asthma" by a farm childhood may primarily reflect protection against atopy, and less against wheezing illness as such. In the farm work environment, with its much higher airborne microbial exposures, the risk of non-atopic wheezing may prevail, so that beneficial effects preventing atopy are outweighed by the enhanced risk of innate immunitymediated non-allergic (non-atopic) respiratory disease.

\section{Exposure and prevention}

In farming occupations there is a challenge for exposure assessment, due to the many different substances, see Table 4. Details related to the methods available for monitoring dust, microbial and allergen concentrations in occupational as well as environmental settings have been published elsewhere [105-110]. For a detailed review on other exposures in farming, please see [1,110-112].

\section{Exposure levels}

Evidently, most of the available data on workplace exposure levels concern dust, endotoxins and $(1 \rightarrow 3)-\beta$-Dglucans. Organic dust is frequently used as a marker of 
exposure to bio-aerosols whereas information regarding levels of other airborne exposures is scarce. Readers interested in such studies are recommended to look elsewhere $[37,113]$.

Overall, studies have shown great variations in personal exposures both between and within different farm types (Table 5). Average personal concentrations of dust are reported to range between 0.2 and $11.2 \mathrm{mg} \mathrm{m}^{-3}$ with content of endotoxin and glucan concentrations averaging between 13 and $9609 \mathrm{EU} \mathrm{m}^{-3}$ and 223 and $10,300 \mathrm{ng} \mathrm{m}^{-3}$, respectively. Pig and poultry farmers are the highest exposed, whereas mixed production and mink-farmers are the lowest exposed, irrespectively of the agent concerned. The available data related to airborne levels of specific allergens in stables are limited, however, to dairy and horse stables. Samadi et al. measured personal and stationary levels of bovine (Bos $d$ 2) allergens in 23 diary stables in the Netherlands [114]. Personal levels of exposure ranged from 0.10 to $46.8 \mu \mathrm{g} / \mathrm{m}^{-3}$ with an average (GM) of $1.47 \mu \mathrm{g} \mathrm{m}^{-3}$, and were generally higher than the measured stationary levels $(\mathrm{GM}=0.66$ $\mu \mathrm{g} \mathrm{m}^{-3}$; range: 0.03 to $35.6 \mu \mathrm{g} \mathrm{m}^{-3}$ ). These concentrations generally exceed those reported in the only earlier study available concerning levels among Finish diary barns by 2 to 3 folds [115]. Similar deviations have been reported in average allergen concentrations measured within horse stables [116-118].

Other important biological agents include ergosterol, muramic acid [119] and mycotoxins [120-122]. Ergosterol and muramic acid are considered markers for exposures to fungal and Gram-negative bacterial, respectively. The health effects of mycotoxins are well described, but their quantification within workplace environments, including farming, remains poor [113].

Exposure studies employing repeated measurements (i.e. measuring the same workers on more than one working day) suggest that the levels of exposure to bioaerosols vary considerably both across different days for the same worker and between different workers that perform the same job $[1,114,123]$. A recent systematic review suggested that average levels of personal dust and endotoxin exposures in livestock farming remained relatively unchanged (i.e. no temporal trends were observed) in the period between 1985 and 2013 [1]. In a more elaborated approach an almost $2 \%$ annual decline in exposure was revealed for the period 1992-2008. The utilized exposure database did not solely comprise measurements from primary agriculture production, and when models were restricted to measurements only from pig farming no time trends seemed to be present (Basinas et al. in preparation).

\section{Factors affecting exposure during farm work}

Bio-aerosol sources are abundant in both indoor and outdoor farm working environments. The environmental conditions and workplace characteristics, as well as the activities performed, are suggested to determine the personal exposures of farmers. Previous research has shown that personal exposures are highest during stable activities involving feed handling, distribution of bedding, intense handling of active animals (e.g. weighing, transport, re-penning and loading) and high pressure washing $[43,111,124-128]$ and lowest during field work, and for cattle farming, the repair of stables and the hosing of parlours following end of the milking process [128-130]. Grain threshing and handling related activities such as storage have also been reported to increase personal levels of bio-aerosol exposures [131].

Besides working tasks, the effect of environmental and farm characteristics has also been assessed in a few studies, of which some have been performed in years prior to the ones covered by the present review (Table 6). Feeding, flooring and ventilation parameters (e.g. type, coverage, system employed) have also been suggested to be strong predictors of in-door personal exposure levels to bio-aerosols [43, 111, 124, 132, 133]. An increased outdoor temperature and the summer season, both indicators of high ventilation rates, have been shown to decrease personal levels of exposure for workers in stables irrespectively of the type of production involved [43,111, 119, 124, 126, $128,129,133,134]$. The general hygiene within the stable has also been shown to influence exposure, whereas for poultry farmers factors such as the age of the chickens involved and the housing system (e.g. aviary vs cage) seem to be of importance. An interesting and consistent observation in recent studies, is a strong association of robot milking in diary stables with an increased exposure of workers to dust and glucans $[114,128,135]$. This effect has been suggested to reflect altered working patterns combined with an increased ratio of animals per worker [128]. Such results of process alterations may be apparent also in other types of production influenced by the tendency towards enlarged productions in Western countries resulting in workers that have less intermittent working tasks and thus more permanent patterns of exposure [1]. Hence, there is an increased demand for effective exposure control and prevention strategies for such workers.

\section{Preventive interventions in farming workers}

Although the farm environment is considered to be allergenic, irritant and toxic for human airways, farmers' knowledge about occupational risks and safety rules seems to be modest $[68,136]$ and medical recognitions of farm WR respiratory diseases are underestimated 


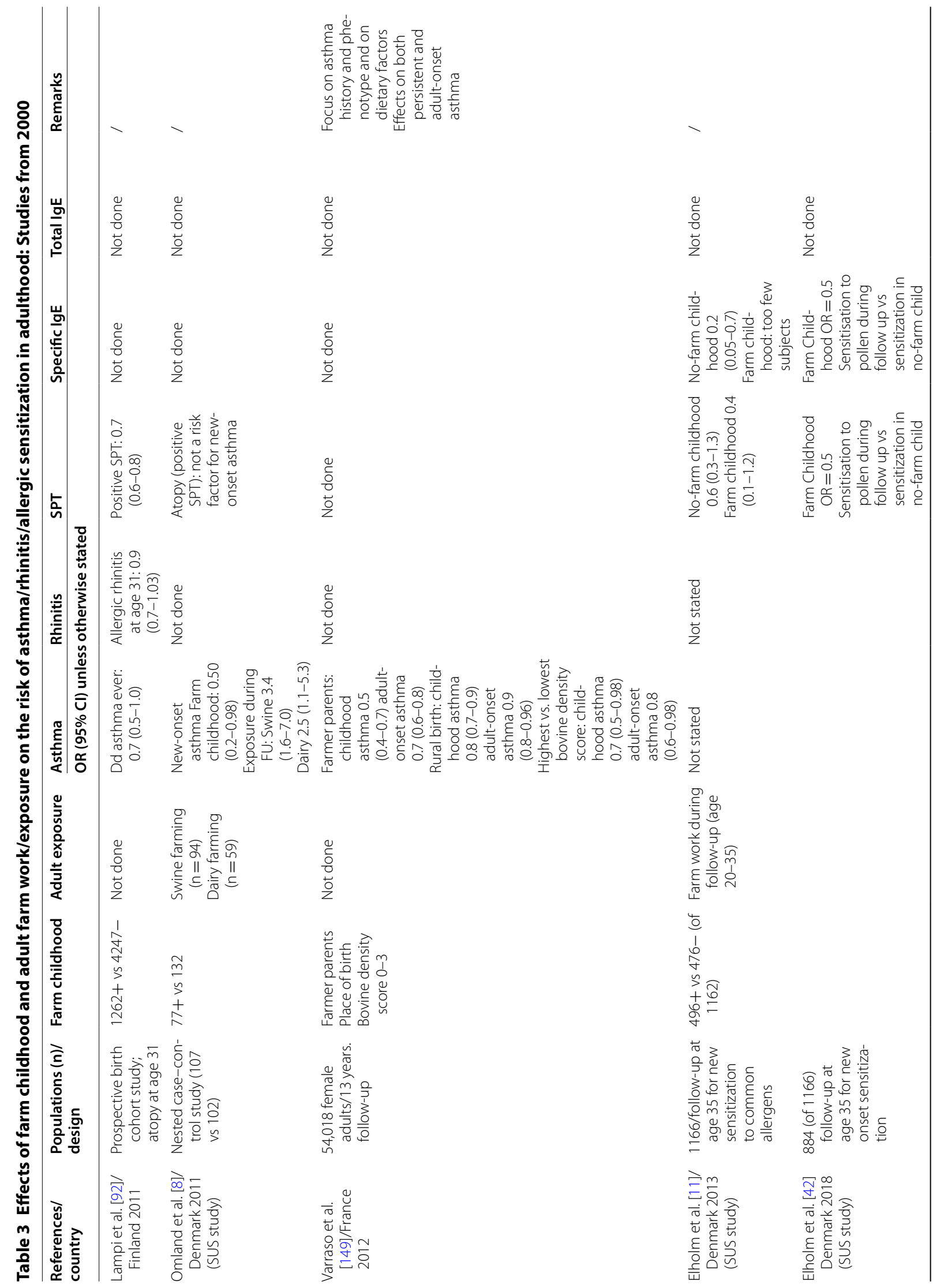


Sigsgaard et al. Chin Transl Allergy <wide> <wide> <wide> (2020) 10:29

Page 17 of 30

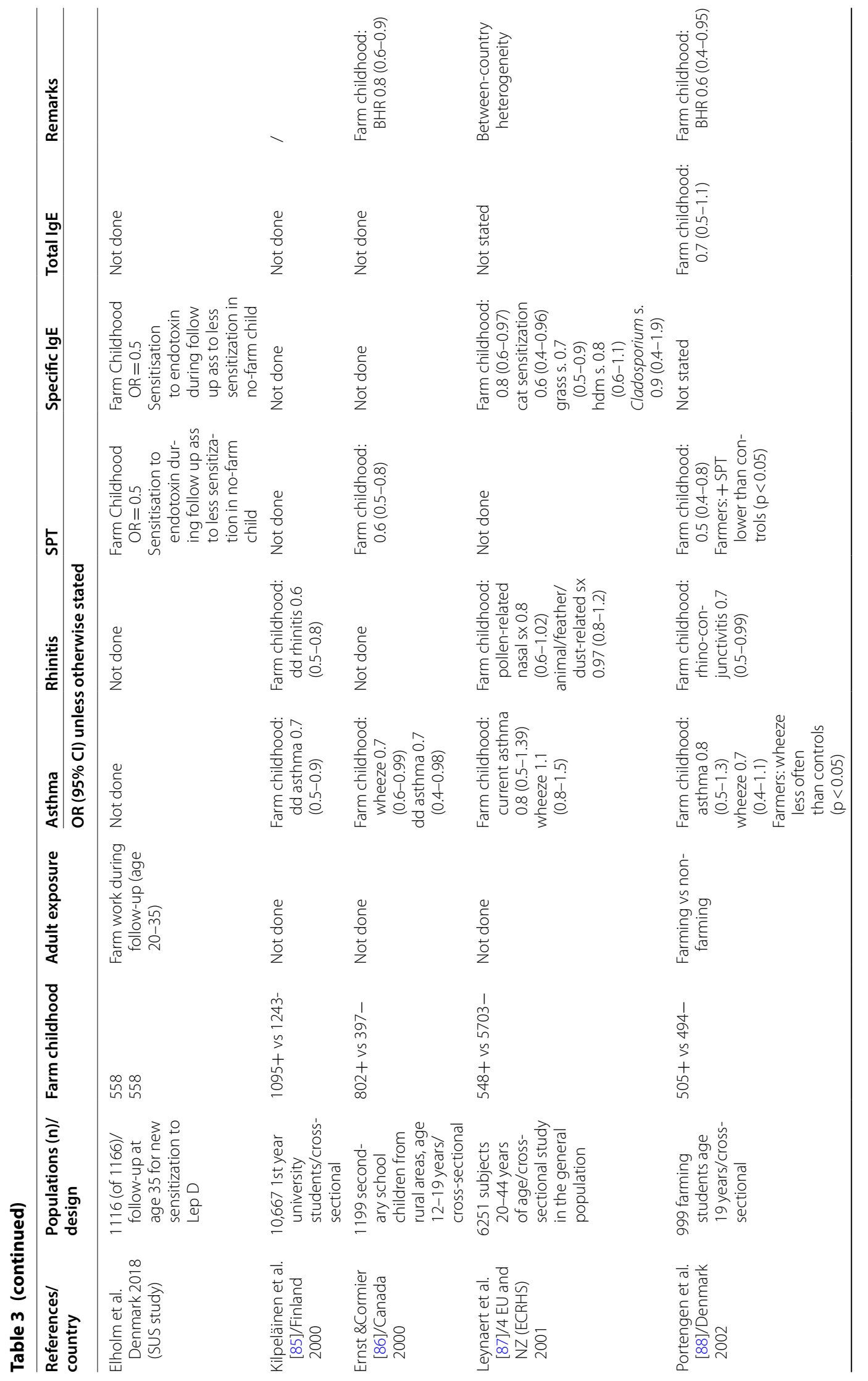




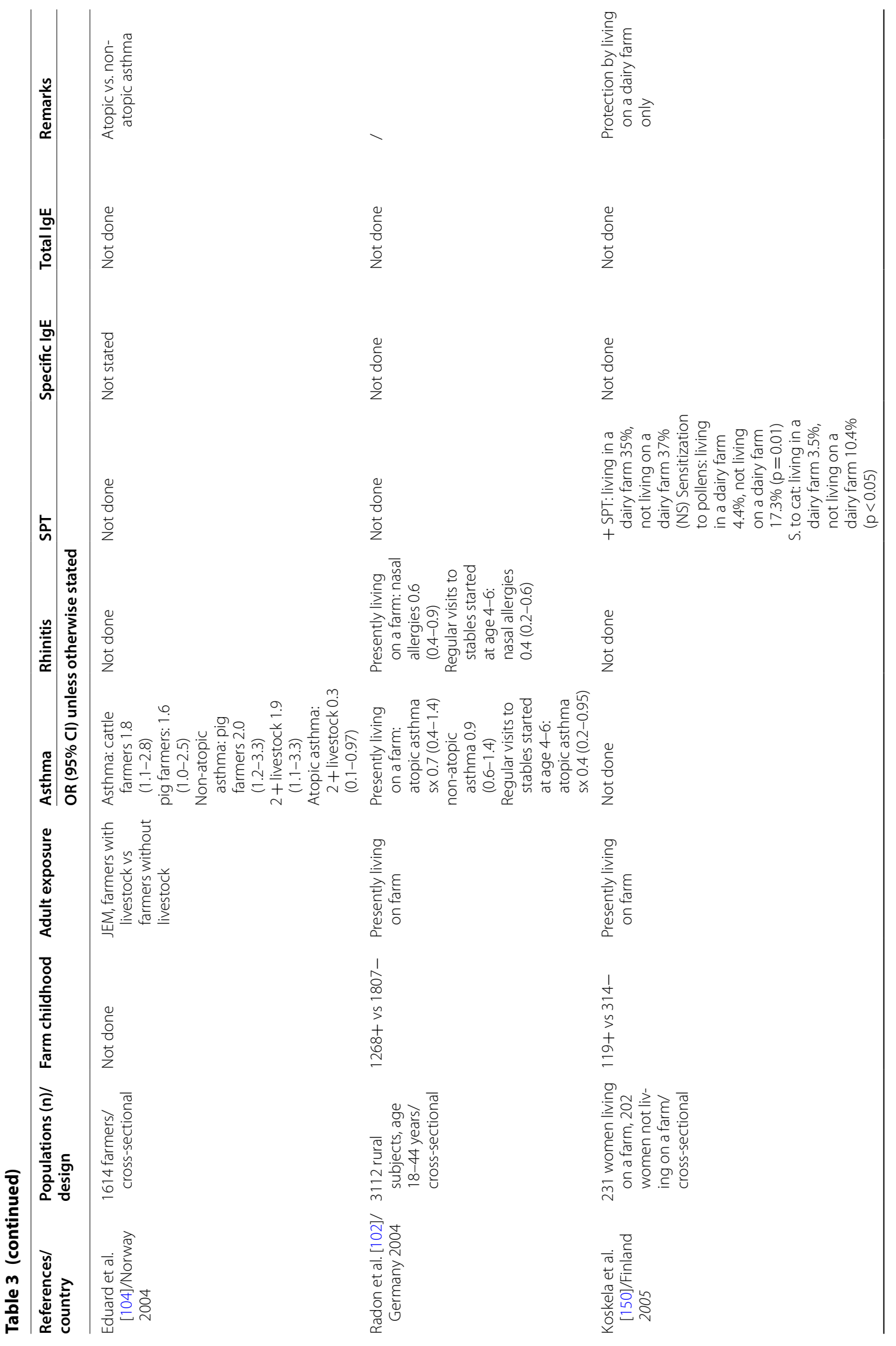




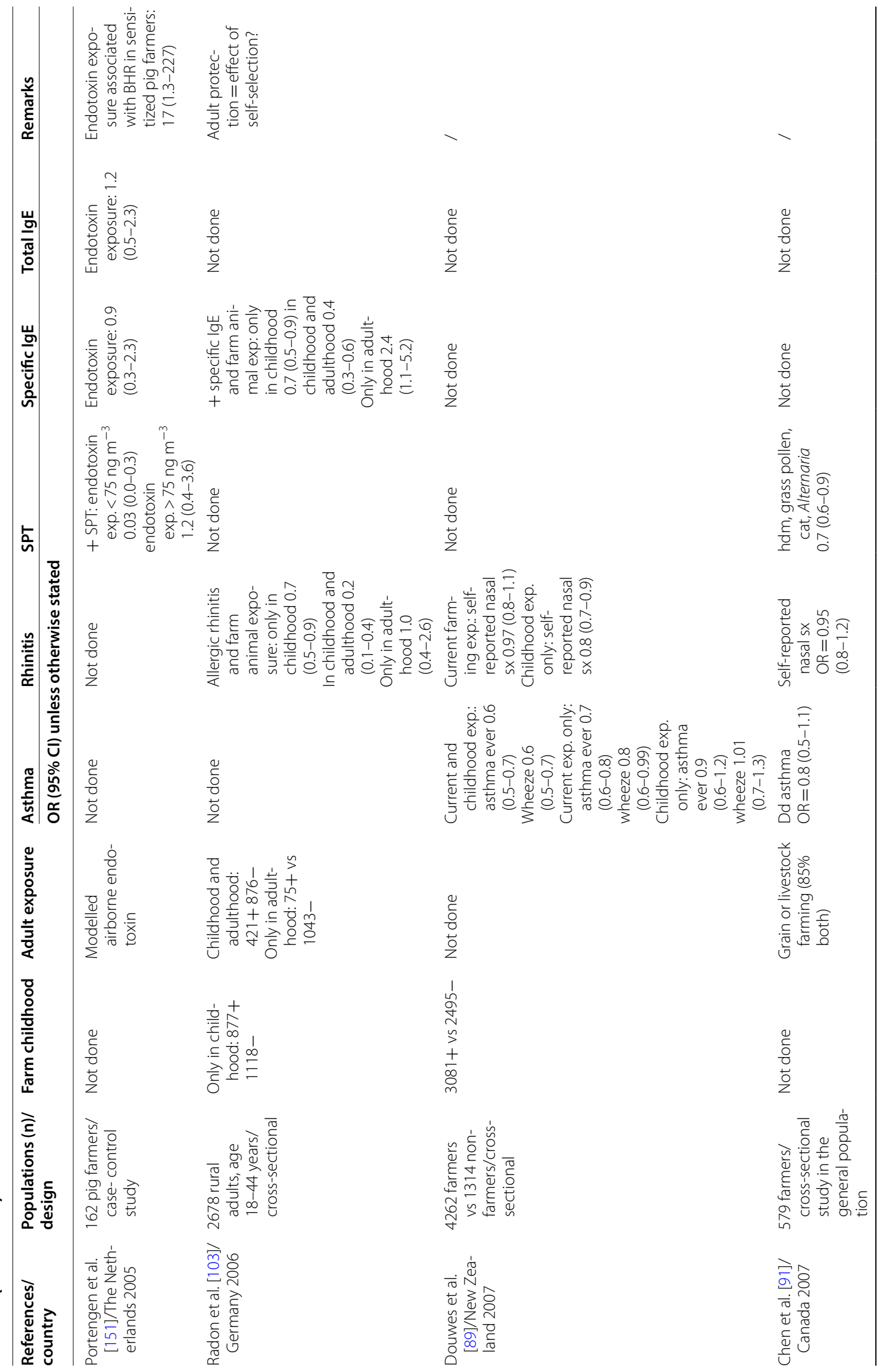




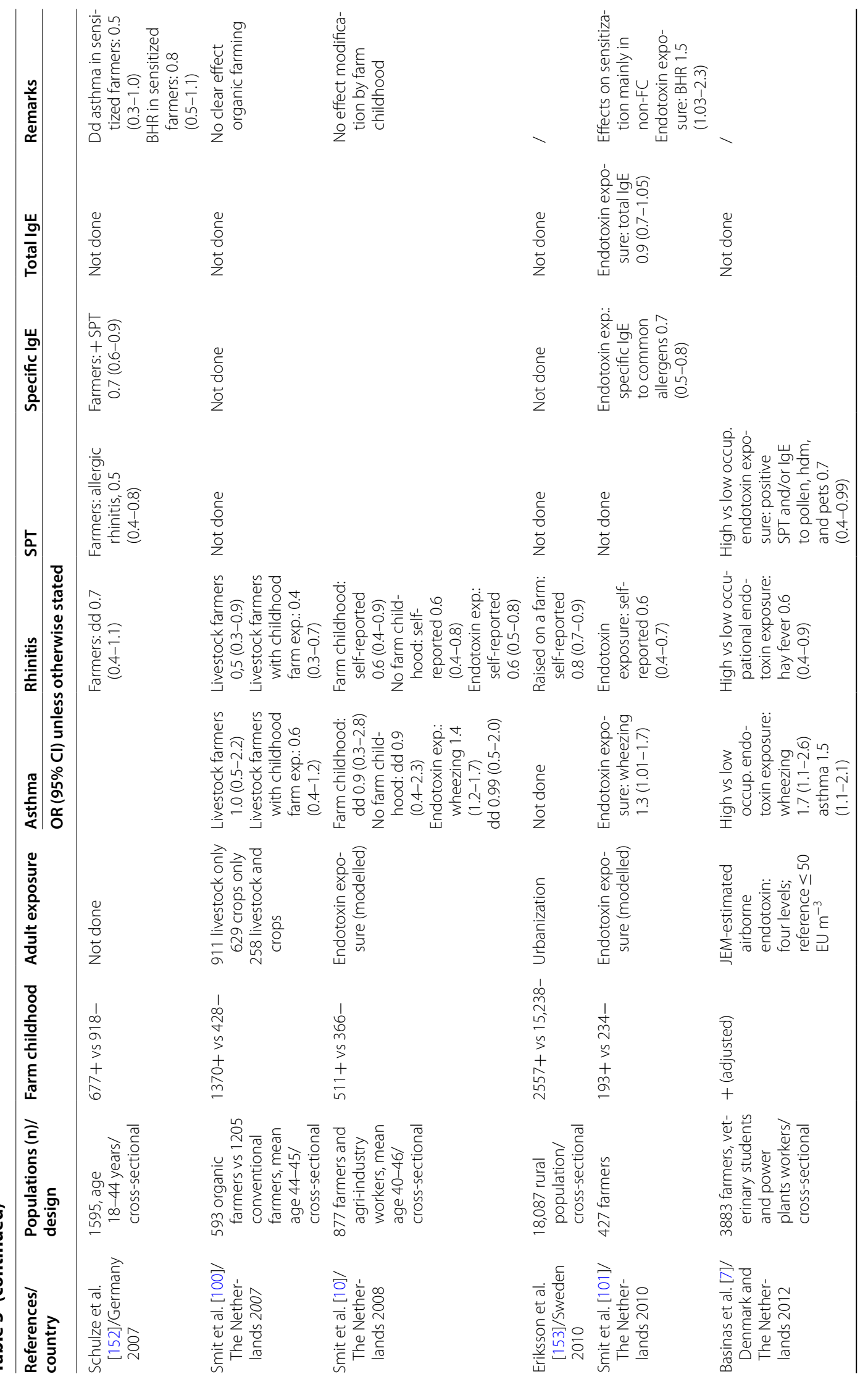




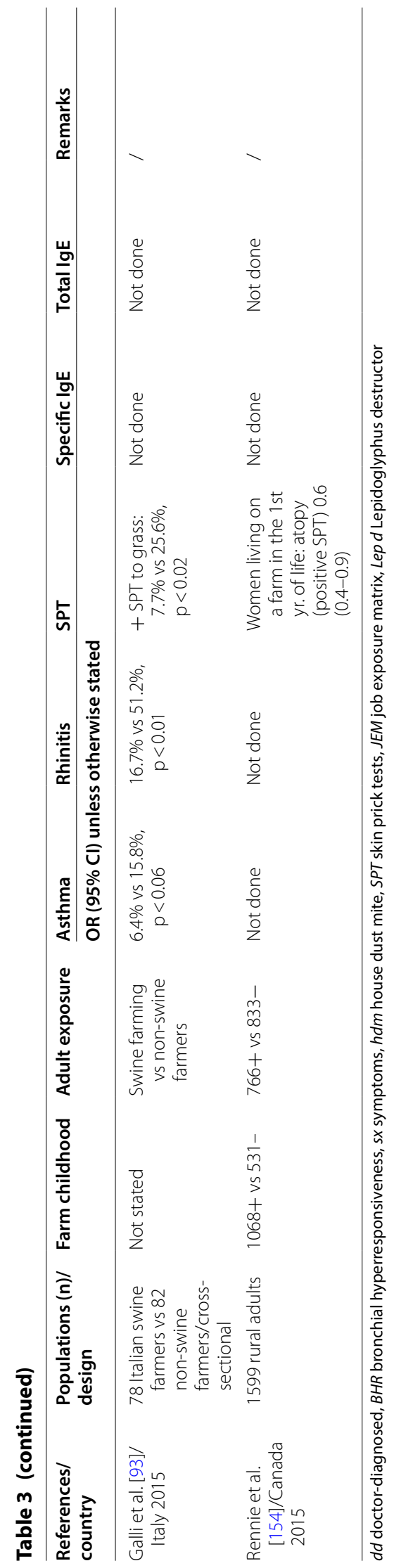


Table 4 Bioaerosol-components in farming environment

\begin{tabular}{|c|c|}
\hline Substance & Method of determination \\
\hline Allergens & Antibody-based assays (sandwich) ELISA \\
\hline Bacteria and Vira & $\begin{array}{l}\text { Viable sampling, microscopic analysis of samples, Non culture-based microbiological } \\
\text { markers or surrogate markers such as endotoxin (Gram negatives), muramic acid } \\
\text { (Gram positives) DNA or RNA based molecular methods ranging from qPCR to } 165 \\
\text { microbiome or full metagenomic analysis C }\end{array}$ \\
\hline Endotoxin & Classical "LAL-test" (kinetic chromogenic test) or recombinant factor C assay \\
\hline $\operatorname{Beta}(1 \rightarrow 3)$ glucan & Factor G pathway of the LAL-test or poly-/monoclonal antibody assays (ELISA) \\
\hline Pyrogenic activity & Whole blood assay (outcome: IL-1ß, IL-6 release) \\
\hline Moulds & $\begin{array}{l}\text { Cultivation of fungi Non culture-based microbiological marker Surrogate markers } \\
\text { like ergosterol or extra-cellular polysaccharides specific for Pen/Asp (EPS) DNA } \\
\text { or RNA based molecular methods ranging from qPCR to ITS or full metagenomic } \\
\text { analysis }\end{array}$ \\
\hline Fungal fragments & Non-gonomorphic particles (Halogen immunoassay) \\
\hline Mycotoxins & ELISA LC-MS (indirect assessment by analyzing settle dust) Biomonitoring \\
\hline
\end{tabular}

[137]. The results of 14-year study including nearly 3500 farmers with occupational diseases indicate the necessity for implementing periodic health examination programs and improving working conditions of agricultural workers [138]. One study of exposure levels was able to demonstrate an effect of feed-back vs no feed-back to the farmers on their own exposure level plus the mean of the other farms. In this study feed-back was associated with lower levels during a repeated measuring campaign 6 months later [139]. Programs based solely on increased use of respirators may not be effective and/or efficient in depth of time; respirator use is as a low tier prevention approach with efficiency strongly dependent on type, proper use and worker behavior [140]. In asthma and rhinitis, avoidance of further exposure to causal agents is recommended, but this may not be achievable in farming populations, mainly due to socio-economic considerations. Therefore a comprehensive strategy of combining interventions towards reduction of harmful workplace exposures, with periodic medical check-ups and treatment optimization is urgently needed.

\section{Research needs}

In each of the preceding chapters, serious gaps in current knowledge of rhinitis and asthma in livestock farmers are identified that require well-designed future research.

- Follow-up studies: Most population studies had primarily a cross-section design, and only a few also a longitudinal follow-up over periods of more than 2-5 years. Most worthwhile would be studies in which the long-term development of respiratory health (symptom prevalence and severity, BHR, lung function, allergic sensitization) is monitored in farmers with and without more or less severe symptoms, and who either left farming, or remained in farm work with or without changing work practices or jobs within agriculture such that exposures were strongly diminished.

- Mechanisms and diagnosis: The pathophysiology of respiratory disease in farmers has been thoroughly studied, including the role of various cell types, cytokines, etc., in innate immunity reactions that may be the predominating cause of most farm and microbial dust-induced illness. In contrast to type I allergy, where specific SPTs or IgE tests and measurement of occupational allergens can be used. Hence, there are no diagnostic tools available with which clinicians can identify innate immunity-mediated reactions to farm and microbial dust causing URT and LRT illness in farmers. Future research thus may focus on development of tests of markers of acute or chronic innate immunity reactions (e.g. patterns of cytokines in blood, nasal or bronchial lavages). Such tests should-possibly in combination with other markers like BHR, and with the help of more sophisticated algorithms-improve diagnosis and prognosis of farm dust and livestock-associated respiratory disease.

- Prevention and intervention: intervention measures have been largely limited to educational activities and incidental studies on effectiveness of technical measures to reduce dust and microbial exposures and use of personal protective devices. Further studies need to include more systematic studies with sufficient power and follow-up to assess effects of interven- 


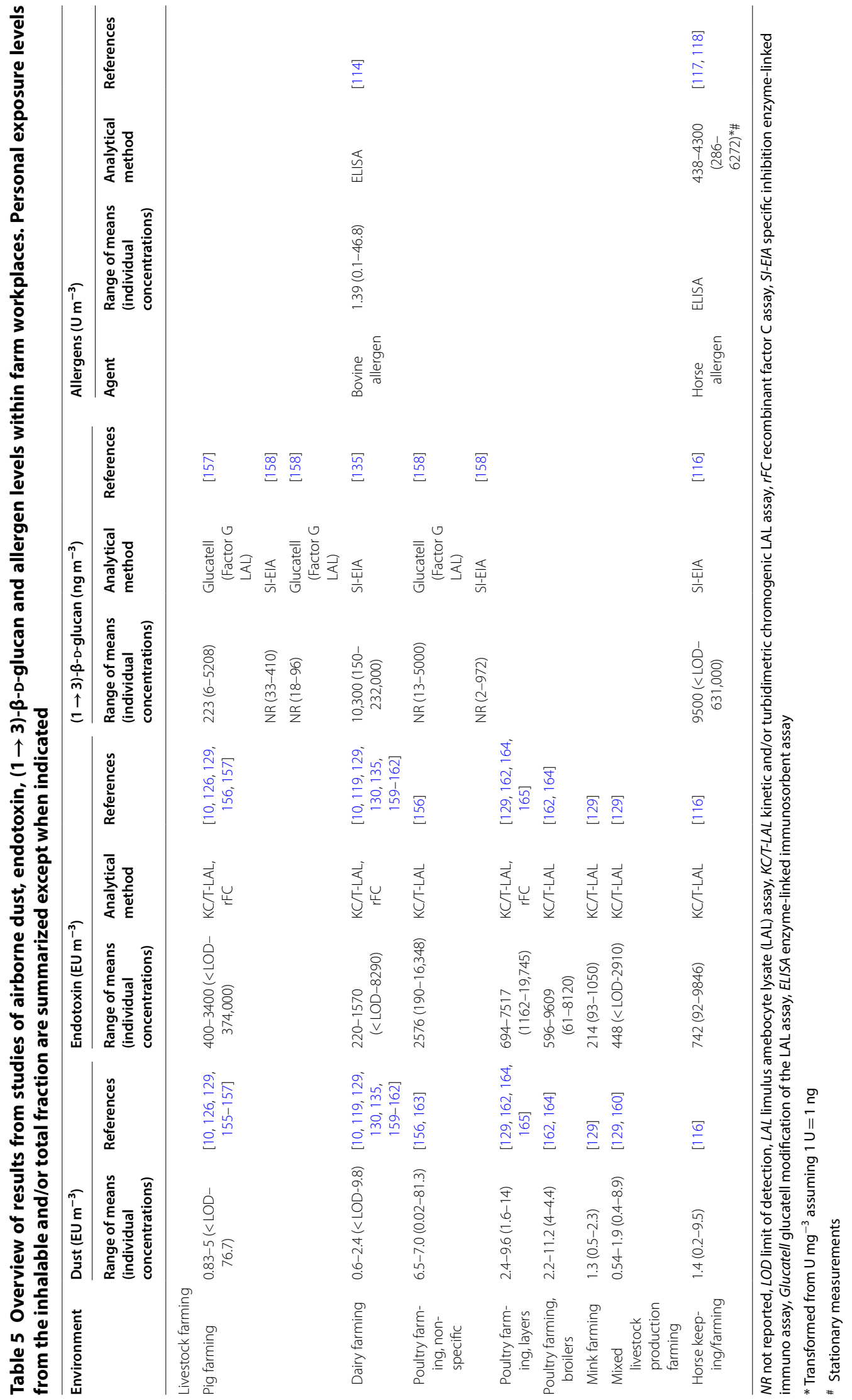


Table 6 Literature reported engineering and production parameters affecting personal exposures of farmers to bioaerosols

\begin{tabular}{|c|c|c|c|c|}
\hline Determinant & Substance & Factor & Estimated effect & Source \\
\hline \multicolumn{5}{|l|}{ Pigs } \\
\hline \multirow[t]{2}{*}{ Environment } & Dust, endotoxin & Season, summer & $\begin{array}{l}\text { Lower levels of exposure compared } \\
\text { to winter }\end{array}$ & {$[43,124,126,129]$} \\
\hline & Dust, endotoxin & Outdoor temperature & $\begin{array}{l}18-36 \% \text { decrease in levels per } 10^{\circ} \mathrm{C} \\
\text { increase in temperature }\end{array}$ & {$[43,124]$} \\
\hline Production stage & Dust & Finishing units & $\begin{array}{l}\text { Exposures highest in finishing and/ } \\
\text { or weaning stables and lowest in } \\
\text { farrowing and/or breading. }\end{array}$ & {$[166,167]$} \\
\hline \multirow[t]{3}{*}{ Ventilation } & Dust & Negative pressure & $\begin{array}{l}\text { lower exposures compared with } \\
\text { neutral or mixed methods by } \\
26-50 \%\end{array}$ & {$[43]$} \\
\hline & Dust, endotoxin & $\begin{array}{l}\text { Air exhaust via other compartments } \\
\text { or the pit }\end{array}$ & $\begin{array}{l}\text { Increased exposures relative to } \\
\text { when characteristic not present } \\
\text { by } 28-42 \%\end{array}$ & {$[124]$} \\
\hline & Endotoxin & Use of a showering system & $\begin{array}{l}\text { 7\% increase of exposure per } 10 \text { min } \\
\text { spent on presence of character- } \\
\text { istic }\end{array}$ & {$[43]$} \\
\hline \multirow[t]{4}{*}{ Feeding } & Dust & Automatic feeding & $\begin{array}{l}\text { Lower exposures with increased } \\
\text { time spent on presence }\end{array}$ & {$[124]$} \\
\hline & Dust, endotoxin & Wet feed & $\begin{array}{l}\text { Lower levels when compared with } \\
\text { dry feed by } 21-79 \%\end{array}$ & {$[43,124]$} \\
\hline & Dust & Fat in feed & $\begin{array}{l}\text { Increased fat content associated } \\
\text { with lower levels of exposure }\end{array}$ & {$[132]$} \\
\hline & Dust & Ad libitum feeding & $\begin{array}{l}\text { 5\% increase in levels per } 10 \text { min } \\
\text { spent on presence of the charac- } \\
\text { teristic }\end{array}$ & {$[43]$} \\
\hline \multirow[t]{3}{*}{ Flooring } & Endotoxin & Full slatted floor & $\begin{array}{l}\text { Full slatted floor associated with } \\
\text { increased exposure levels by } 50 \% \\
\text { compared with a full concrete or } \\
16 \% \text { for every } 10 \text { min spent on } \\
\text { presence }\end{array}$ & {$[43,124]$} \\
\hline & Dust & Fully concrete floor & $\begin{array}{l}\text { Fully concrete floor associated with } \\
21 \% \text { decrease in dust exposure }\end{array}$ & {$[124]$} \\
\hline & Endotoxin & floor heating & $\begin{array}{l}38 \% \text { increase in exposures per } \\
10 \text { min spent on presence }\end{array}$ & {$[124]$} \\
\hline \multirow[t]{2}{*}{ General hygiene } & Dust, endotoxin & Very dusty stable & $\begin{array}{l}\text { 7-18\% increased exposure com- } \\
\text { pared to a non-dusty environment }\end{array}$ & {$[124]$} \\
\hline & Dust & Wet floor & $\begin{array}{l}\text { Reduced levels compared to dry } \\
\text { floor by } 12 \%\end{array}$ & {$[168]$} \\
\hline Other & Dust & $\begin{array}{l}\text { Ventilation and floor, and manure } \\
\text { type combinations }\end{array}$ & $\begin{array}{l}\text { Exposures lowest in natural venti- } \\
\text { lated buildings with slatted floors. } \\
\text { Highest exposures in mechanically } \\
\text { ventilated buildings with scrapper } \\
\text { manure collection. }\end{array}$ & {$[169]$} \\
\hline \multicolumn{5}{|l|}{ Cattle } \\
\hline Environment & Endotoxin & Outdoor temperature & $\begin{array}{l}\geq 18 \% \text { decrease in levels per } 100 \mathrm{C} \\
\text { increase in temperature }\end{array}$ & {$[111,119,128]$} \\
\hline \multirow[t]{2}{*}{ Feeding } & Endotoxin & Semi-automatic system & $\begin{array}{l}42 \% \text { reduction compared to manual } \\
\text { feeding }\end{array}$ & {$[111]$} \\
\hline & Dust & Amount of feed (pellet, meal) & $\begin{array}{l}\text { 2\% increase in exposure per kg } \\
\text { distributed }\end{array}$ & {$[111]$} \\
\hline Bedding & Dust, endotoxin, glucans & Compost bedding & $\begin{array}{l}\text { Compost bedding associated with } \\
\text { higher exposures compared to } \\
\text { rubber mats by } 5 \% \text { for dust and } \\
179 \text { to } 400 \% \text { for the constituents }\end{array}$ & {$[114,135]$} \\
\hline
\end{tabular}


Table 6 (continued)

\begin{tabular}{|c|c|c|c|c|}
\hline Determinant & Substance & Factor & Estimated effect & Source \\
\hline Animal density & Dust, endotoxin, bovine allergens & Surface area per cow & $\begin{array}{l}\text { Increased surface associated with } \\
\text { decreased levels of exposure by } \\
7 \text { to } 65 \%\end{array}$ & {$[114,115,135]$} \\
\hline \multirow[t]{2}{*}{ Manure handling } & Dust & Automatic scrapers in alley ways & $\begin{array}{l}40 \% \text { reduction compared to when } \\
\text { system not used }\end{array}$ & {$[128]$} \\
\hline & Endotoxin & Slope or back flashed system in pit & $\begin{array}{l}175 \% \text { increase compared to round } \\
\text { or scraper based systems }\end{array}$ & [128] \\
\hline Milking & Dust, glucans, bovine allergens & Robot & $\begin{array}{l}\text { Robots associated to increased } \\
\text { exposure compared to parlour } \\
\text { milking by } 22-86 \% \text { for dust and } \\
138 \% \text { for glucans but decreased } \\
\text { exposures to bovine allergens by } \\
65 \% \text {. }\end{array}$ & {$[114,128,135]$} \\
\hline General hygiene & Dust, endotoxin & Parlour cleaning & $\begin{array}{l}\text { Increased frequency of parlor clean- } \\
\text { ing associated with lower levels of } \\
\text { dust and endotoxin }\end{array}$ & {$[170]$} \\
\hline \multicolumn{5}{|l|}{ Poultry } \\
\hline Environment & Dust, endotoxin & Season, summer & $\begin{array}{l}\text { Somewhat lower levels of exposure } \\
\text { compared to winter for layers, and } \\
\text { turkey farmers }\end{array}$ & {$[133,134]$} \\
\hline \multirow[t]{2}{*}{ Barn system } & Dust, endotoxin & Floor (aviary) & $\begin{array}{l}\text { Floor (Aviary) housing system results } \\
\text { in higher concentrations relatively } \\
\text { to cage housing }\end{array}$ & {$[165,171,172]$} \\
\hline & Dust & Enclosed system & $\begin{array}{l}\text { Higher exposures in systems that } \\
\text { are enclosed (only mechanical } \\
\text { ventilated) compared to those } \\
\text { being open with both mechanical } \\
\text { and natural ventilation present }\end{array}$ & {$[134]$} \\
\hline \multirow[t]{3}{*}{ Production stage } & Dust, endotoxin & Flock age & $\begin{array}{l}\text { Increased flock age associated with } \\
\text { decreased exposures }\end{array}$ & {$[129,134,164]$} \\
\hline & Dust, endotoxin & Parent stock & $\begin{array}{l}\text { Levels in parent stock farm higher } \\
\text { compared to broiler and layers }\end{array}$ & {$[134]$} \\
\hline & Dust, endotoxin & Hen (Turkey) & $\begin{array}{l}\text { Levels in hen stables higher } \\
\text { compared to those of toms and } \\
\text { brooders }\end{array}$ & {$[133]$} \\
\hline Ventilation & Dust, endotoxin & Ventilation rate & $\begin{array}{l}\text { Increased ventilation rate related to } \\
\text { decreased levels of exposure }\end{array}$ & {$[133]$} \\
\hline General hygiene & Dust, endotoxin & Litter presence in control alleys & $\begin{array}{l}\text { Presence of litter in control alleys } \\
\text { assoc. with higher exposures } \\
\text { compared to no presence }\end{array}$ & {$[134]$} \\
\hline Other & Dust, endotoxin & Tilling of litter & $\begin{array}{l}\text { Performance of litter tilling related } \\
\text { with increased levels of exposure }\end{array}$ & {$[133]$} \\
\hline
\end{tabular}

tions both on exposure levels and on the respiratory health of participants.

\section{Conclusion}

In spite of technological changes, the over-all levels of airborne exposure of livestock farmers to organic dusts, including microbial agents and allergens, ammonia and other gases, haven't changed considerably and remained high and is still a serious health hazard.

Accordingly, prevalence and incidence of work-related respiratory disease, including asthma, bronchitis and upper respiratory tract symptoms among workers in livestock farming have remained high.

Causal factors and mechanisms may in some cases be specific farm allergens and IgE-mediated type I sensitization - to e.g. storage mite, bovine or horse allergens -, but the large majority of work-related respiratory symptoms in livestock farmers is caused by innate immunity responses to microbial agents like bacterial endotoxins, glucans and other innate immunity stimulating agents, thus leading to 'non-allergic asthma' and bronchitis.

A thorough anamnesis and identification of symptoms as clearly exposure-associated is the key point in 
the diagnosis of work related upper- and lower respiratory tract diseases in farmers. Even if common atopy and NSBHR are strong risk factors, the diagnostic procedure cannot depend entirely on IgE serology, specific inhalation challenge or other tests for specific immunologic sensitization.

Since many farm workers have been raised on a farm, the well-known protective effect of a farm childhood against atopic sensitization, allergic asthma and rhinitis can also be found in adult farm workers. Results of several studies suggest that farm exposure in adulthood may provide an additional protective effect. This protection however appears to be largely limited to atopic sensitization, particularly to pollen, and hardly affects the enhanced risk of non-allergic asthma in farm workers.

\section{Supplementary information}

Supplementary information accompanies this paper at https://doi. org/10.1186/s13601-020-00334-x.

Additional file 1. Appendix S1 Search strategy.

\begin{abstract}
Abbreviations
BHR: Bronchial hyper-responsiveness; CAFOs: Concentrated animal feeding operation; ECRHS: European Community Respiratory Health Survey; HWS: Healthy worker selection; LRT: Lower respiratory tract; NOD: Nucleotidebinding oligomerization domain; NSBHR: Nonspecific bronchial hyper-responsiveness; ODTS: Organic dust toxic syndrome; PAMPs/MAMPs: Pathogen- and microbial-associated molecular patterns; PGRPs: Peptidoglycan recognition proteins; SIC: Specific inhalation challenge; SPTs: Skin prick tests; SUS: Study of young farmers; TLR: Toll-like receptors; URT: Upper respiratory tract; LRT: Lower respiratory tract; WR: Work-related.
\end{abstract}

\section{Acknowledgements}

Not applicable.

\section{Authors' contributions}

TS and AS conceived the task force. TS planned and performed the review. GD, IB and TS wrote the second draft of the manuscript. All authors contributed in the collection of original studies, and drafting the different sections of the first draft, discussion of the analysis and interpretation of studies. All authors read and approved the final manuscript.

\section{Funding}

Supported by the EAACI Task Force Grant (40189)

\section{Availability of data and materials \\ Not applicable.}

\section{Ethics approval and consent to participate}

Not applicable.

\section{Consent for publication}

All Authors have read and give their consent for publication.

\section{Competing interests}

The authors declare that they have no competing interests.

\section{Author details}

${ }^{1}$ Department of Environment Occupation \& Health, Dept of Public Health, Danish Ramazzini Centre, Aarhus University, Bartholins Allé 2, Build. 1260, 8000 Aarhus C, Denmark. ${ }^{2}$ Institute of Occupational Medicine, Edinburgh,
UK. ${ }^{3}$ Division of Environmental Epidemiology, Institute for Risk Assessment Sciences, Utrecht University, Utrecht, The Netherlands. ${ }^{4}$ Division of Asthma and Allergy, Department of Chest Diseases, University Hospital, Fédération de Médecine Translationnelle de Strasbourg, Strasbourg University, Strasbourg, France. ${ }^{5}$ Occupational Medicine, Terni Hospital, University of Perugia, Perugia, Italy. ${ }^{6}$ Department of Occupational Diseases and Environmental Health, Nofer Institute of Occupational Medicine, Lodz, Poland. ${ }^{7}$ Institute and Clinic for Occupational, Social and Environmental Medicine, University Hospital, Ludwig Maximilian University, Munich, Germany. ${ }^{8}$ Comprehensive Pneumology Center Munich, Member DZL, German Centre for Lung Research, Munich, Germany. ${ }^{9}$ Unit of Occupational Medicine, Department of Diagnostics and Public Health, University of Verona, Verona, Italy. ${ }^{10}$ Department of Allergy, Hospital La Paz Institute for Health Research (IdiPAZ) and CIBER de Enfermedades Respiratorias (CIBERES), Madrid, Spain. ${ }^{11}$ IPA Institute for Prevention and Occupational Medicine of the German Social Accident Insurance, Institute of the Ruhr-Universität Bochum, Bochum, Germany. ${ }^{12}$ Department of Allergy, Fundación Jiménez Díaz, CIBER de Enfermedades Respiratorias (Ciberes), Madrid, Spain. ${ }^{13}$ Formerly Department of Clinical and Experimental Medicine, University of Perugia, Perugia, Italy.

Received: 5 June 2020 Accepted: 11 June 2020

Published online: 06 July 2020

\section{References}

1. Basinas I, Sigsgaard T, Kromhout $H$, Heederik D, Wouters IM, Schlunssen V. A comprehensive review of levels and determinants of personal exposure to dust and endotoxin in livestock farming. J Eposure Sci Environ Epidemiol. 2015;25(2):123-37.

2. Development D-GfAaR. Agriculture in the European Union, Statistical and Economic Information. In: Development D-GfAaR, editor. Brussels: European Union; 2013.

3. Roser M. Employment in agriculture. OurWorldInData.org: urWorldlnData; 2020. https://ourworldindata.org/employment-in-agriculture.

4. Schenker M, Christiani D, Cormier Y, Dimich-Ward H, Doekes G, Dosman JA, et al. Respiratory health hazards in agriculture. Am J Respir Crit Care Med. 1998;158(supplement 1):S1-76.

5. Wunschel J, Poole JA. Occupational agriculture organic dust exposure and its relationship to asthma and airway inflammation in adults. J Asthma. 2016;53(5):471-7.

6. Chiarella SE, Fernandez R, Avila PC. The genes and the environment in nasal allergy. Curr Opin Allergy Clin Immunol. 2015;15(5):440-5.

7. Basinas I, Schlunssen V, Heederik D, Sigsgaard T, Smit LA, Samadi S, et al. Sensitisation to common allergens and respiratory symptoms in endotoxin exposed workers: a pooled analysis. Occup Environ Med. 2012;69(2):99-106.

8. Omland O, Hjort C, Pedersen OF, Miller MR, Sigsgaard T. New-onset asthma and the effect of environment and occupation among farming and nonfarming rural subjects. J Allergy Clin Immunol. 2011;128:761-5.

9. Gern JE. Promising candidates for allergy prevention. J Allergy Clin Immunol. 2015;136(1):23-8.

10. Smit LA, Heederik D, Doekes G, Blom C, van Zweden I, Wouters IM. Exposure-response analysis of allergy and respiratory symptoms in endotoxin-exposed adults. Eur Respir J. 2008;31(6):1241-8.

11. Elholm G, Schlunssen V, Doekes G, Basinas I, Bibby BM, Hjort C, et al. Become a farmer and avoid new allergic sensitization: adult farming exposures protect against new-onset atopic sensitization. JAllergy Clinlmmunol. 2013;132(5):1239-41.

12. Quirce S, Vandenplas O, Campo P, Cruz MJ, de Blay F, Koschel D, et al. Occupational hypersensitivity pneumonitis: an EAACI position paper. Allergy. 2016;71(6):765-79.

13. Kogevinas M, Zock JP, Jarvis D, Kromhout H, Lillienberg L, Plana E, et al. Exposure to substances in the workplace and new-onset asthma: an international prospective population-based study (ECRHS-II). Lancet. 2007;370(9584):336-41.

14. Radon K, Weber C, Iversen M, Danuser B, Pedersen S, Nowak D. Exposure assessment and lung function in pig and poultry farmers. Occup Environ Med. 2001;58(6):405-10. 
15. Tutluoglu B, Atis S, Anakkaya AN, Altug E, Tosun GA, Yaman M. Sensitization to horse hair, symptoms and lung function in grooms. Clin Exp Allergy. 2002;32(8):1170-3.

16. Mazan MR, Svatek J, Maranda L, Christiani D, Ghio A, Nadeau J, et al. Questionnaire assessment of airway disease symptoms in equine barn personnel. Occup Med. 2009;59(4):220-5.

17. Radon K, Winter C. Prevalence of respiratory symptoms in sheep breeders. Occup Environ Med. 2003;60(10):770-3.

18. Kronqvist M, Johansson E, Pershagen G, Johansson SG, van HageHamsten M. Risk factors associated with asthma and rhinoconjunctivitis among Swedish farmers. Allergy. 1999;54(11):1142-9.

19. Schenker MB, Farrar JA, Mitchell DC, Green RS, Samuels SJ, Lawson RJ, et al. Agricultural dust exposure and respiratory symptoms among California farm operators. J Occup Environ Med. 2005;47(11):1157-66.

20. Eduard W, Pearce N, Douwes J. Chronic bronchitis, COPD, and lung function in farmers: the role of biological agents. Chest. 2009;136(3):716-25.

21. Magarolas R, Monso E, Aguilar X, Radon K, Nowak D, Martinez C, et al. Prevalence and risk factors of respiratory symptoms in farmers; $\mathrm{Com}^{-}$ ment. Med Clin. 2000;114(18):685-9.

22. Thaon I, Thiebaut A, Jochault L, Lefebvre A, Laplante JJ, Dalphin JC. Influence of hay and animal feed exposure on respiratory status: a longitudinal study. Eur Respir J. 2011;37(4):767-74.

23. Senthilselvan A, Chenard L, Ulmer K, Gibson-Burlinguette N, Leuschen C, Dosman JA. Excess respiratory symptoms in full-time male and female workers in large-scale swine operations. Chest. 2007;131(4):1197-204.

24. Kimbell-Dunn MR, Fishwick RD, Bradshaw L, Erkinjuntti-Pekkanen R, Pearce N. Work-related respiratory symptoms in New Zealand farmers. Am J Ind Med. 2001;39(3):292-300.

25. Gallagher LM, Crane J, Fitzharris P, Bates MN. Occupational respiratory health of New Zealand horse trainers. Int Arch Occup Environ Health. 2007:80(4):335-41.

26. Monso E, Riu E, Radon K, Magarolas R, Danuser B, Iversen M, et al. Chronic obstructive pulmonary disease in never-smoking animal farmers working inside confinement buildings. Am J Ind Med. 2004;46(4):357-62.

27. Marescaux A, Degano B, Soumagne T, Thaon I, Laplante JJ, Dalphin JC. Impact of farm modernity on the prevalence of chronic obstructive pulmonary disease in dairy farmers. Occup Environ Med. 2016;73(2):127-33.

28. Guillien A, Puyraveau M, Soumagne T, Guillot S, Rannou F, Marquette D, et al. Prevalence and risk factors for COPD in farmers: a cross-sectional controlled study. Eur Respir J. 2016;47(1):95-103.

29. Bolund AC, Miller MR, Basinas I, Elholm G, Omland O, Sigsgaard T, et al. The effect of occupational farming on lung function development in young adults: a 15-year follow-up study. Occup Environ Med. 2015;72(10):707-13.

30. Iversen $M$, Dahl R. Working in swine-confinement buildings causes an accelerated decline in FEV1: a 7-yr follow-up of Danish farmers. Eur Respir J. 2000;16(3):404-8.

31. Chaudemanche H, Monnet E, Westeel V, Pernet D, Dubiez A, Perrin C, et al. Respiratory status in dairy farmers in France; cross sectional and longitudinal analyses. Occup Environ Med. 2003;60(11):858-63.

32. Gainet M, Thaon I, Westeel V, Chaudemanche H, Venier AG, Dubiez A, et al. Twelve-year longitudinal study of respiratory status in dairy farmers. Eur Respir J. 2007;30(1):97-103.

33. Chenard L, Senthilselvan A, Grover VK, Kirychuk SP, Lawson JA, Hurst TS, et al. Lung function and farm size predict healthy worker effect in swine farmers. Chest. 2007;131(1):245-54.

34. Bolund AC, Miller MR, Sigsgaard T, Schlunssen V. The effect of organic dust exposure on long-term change in lung function: a systematic review and meta-analysis. Occup Environ Med. 2017;74(7):531-42.

35. Sigsgaard T, Omland $\varnothing$, Thorne PS. Asthma-like diseases in agriculture. In: Sigsggard T, Heederik D, editors. Occupational asthma. Progress in inflammation research. Basel: Birkhäuser Basel; 2010. p. 163-83.

36. Swanberg JE, Clouser JM, Gan W, Mannino DM, Flunker JC. Individual and occupational characteristics associated with respiratory symptoms among Latino horse farm workers. Am J Ind Med. 2015;58(6):679-87.

37. Zahradnik E, Raulf M. Animal allergens and their presence in the environment. Front Immunol. 2014;5:76.
38. Zahradnik E, Raulf M. Respiratory allergens from furred mammals: environmental and occupational exposure. Vet Sci. 2017;4(3):38.

39. Bohlandt A, Schierl R, Heizinger J, Dietrich-Gumperlein G, Zahradnik E, Bruckmaier $\mathrm{L}$, et al. Cow hair allergen concentrations in dairy farms with automatic and conventional milking systems: from stable to bedroom. Int J Hyg Environ Health. 2016;219(1):79-87.

40. Schlunssen V, Basinas I, Zahradnik E, Elholm G, Wouters IM, Kromhout $H$, et al. Exposure levels, determinants and lgE mediated sensitization to bovine allergens among Danish farmers and non-farmers. Int J Hyg Environ Health. 2015;218(2):265-72.

41. Elholm G, Schlunssen V, Doekes G, Basinas I, Omland O, Gronager PM, et al. Adult farming exposure does not protect against sensitization to the storage mite Lepidoglyphus destructor. Allergy. 2018;73(11):2234-7.

42. Elholm G, Schlunssen V, Doekes G, Basinas I, Bolund ACS, Hjort C, et al. High exposure to endotoxin in farming is associated with less newonset pollen sensitisation. Occup Environ Med. 2018;75(2):139-47.

43. Basinas I, Schlunssen V, Takai H, Heederik D, Omland O, Wouters IM, et al. Exposure to inhalable dust and endotoxin among danish pig farmers affected by work tasks and stable characteristics. Ann Occup Hyg. 2013;57:1005-19.

44. Sigsgaard T, Bonefeld-Jorgensen EC, Hoffmann HJ, Bonlokke J, Kruger T. Microbial cell wall agents as an occupational hazard. Toxicol Appl Pharmacol. 2005;207(2 Suppl):310-9.

45. Iversen M, Kirychuk S, Drost $H$, Jacobson L. Human health effects of dust exposure in animal confinement buildings. J Agric Saf Health. 2000;6(4):283-8.

46. Pedersen B, Iversen M, Bundgaard Larsen B, Dahl R. Pig farmers have signs of bronchial inflammation and increased numbers of lymphocytes and neutrophils in BAL fluid. Eur Respir J. 1996;9(3):524-30.

47. Sundblad BM, von Scheele I, Palmberg L, Olsson M, Larsson K. Repeated exposure to organic material alters inflammatory and physiological airway responses. Eur Respir J. 2009;34(1):80-8.

48. Larsson BM, Larsson K, Malmberg P, Palmberg L. Airways inflammation after exposure in a swine confinement building during cleaning procedure. Am J Ind Med. 2002;41 (4):250-8.

49. Palmberg L, Larssson BM, Malmberg P, Larsson K. Airway responses of healthy farmers and nonfarmers to exposure in a swine confinement building. Scand J Work Environ Health. 2002;28(4):256-63.

50. Sundblad BM, Palmberg L, Larsson K. Bronchial responsiveness to eucapnic hyperventilation and methacholine following exposure to organic dust. Chest. 2002;122(1):363-8.

51. Radon K, Garz S, Riess A, Koops F, Monso E, Weber C, et al. Respiratory diseases in European farmers-II. Part of the European farmers' project. Pneumologie. 2003;57(9):510-7.

52. Heutelbeck AR, Junghans C, Esselmann H, Hallier E, Schulz TG. Exposure to allergens of different cattle breeds and their relevance in occupational allergy. Int Arch Occup Environ Health. 2009;82(9):1123-31.

53. Sigsgaard T, Thorne PS, Schlunssen V, Bonlokke J, Riddervold IS, Hoppe $K A$, et al. The change in nasal inflammatory markers after intranasal challenges with particulate chitin and lipopolysaccharide: a randomized, double-blind, placebo-controlled, crossover study with a positive control. Int Forum Allergy Rhinol. 2015;5(8):716-23.

54. Holmstrom M, Thelin A, Kolmodin-Hedman B, Van Hage M. Nasal complaints and signs of disease in farmers - a methodological study. Acta Otolaryngol. 2008;128(2):193-200.

55. Poole JA, LeVan TD, Slager RE, Qiu F, Severa L, Yelinek J, et al. Bronchodilator responsiveness in swine veterinarians. J Agromedicine. 2007;12(2):49-54

56. Radon K, Danuser B, Iversen M, Jorres R, Monso E, Opravil U, et al, Respiratory symptoms in European animal farmers. Eur Respir $\mathrm{J}$. 2001;17(4):747-54.

57. Terho EO, Husman K, Vohlonen I, Rautalahti M, Tukiainen H. Allergy to storage mites or cow dander as a cause of rhinitis among Finnish dairy farmers. Allergy. 1985;40(1):23-6.

58. Dressel H, Gross C, de la Motte D, Sultz J, Jorres RA, Nowak D. Educational intervention in farmers with occupational asthma: long-term effect on exhaled nitric oxide. J Investig Allergol Clin Immunol. 2009;19(1):49-53.

59. Doekes G, Wouters I, de Vries J, Omland, Sigsgaard T, Virtanen T, et al. IgE antobodies to cow allergens and respiratory health in dairy farmers in Denmark and The Netherlands. J Agric Health Safety. 2000;5:309-16. 
60. Poole JA, Romberger DJ. Immunological and inflammatory responses to organic dust in agriculture. Curr Opin Allergy Clin Immunol. 2012;12(2):126-32.

61. Vandenplas O, Suojalehto H, Aasen TB, Baur X, Burge PS, de Blay F, et al. Specific inhalation challenge in the diagnosis of occupational asthma: consensus statement. Eur Respir J. 2014;43(6):1573-87.

62. Moscato G, Vandenplas O, Van Gerth Wijk R, Malo JL, Quirce S, et al. Occupational rhinitis. Allergy. 2008;63(8):969-80.

63. Macek C. Bacterial endotoxin may be culprit in 'Monday fever'. JAMA. 1982;247(20):2765-6.

64. Sigsgaard T, Pedersen OF, Juul S, Gravesen S. Respiratory disorders and atopy in cotton, wool, and other textile mill workers in Denmark. AmJIndMed. 1992;22(2):163-84.

65. EAACI Task Force on Occupational Rhinitis, Sundblad BM, Larsson BM, Palmberg L, Larsson K. Exhaled nitric oxide and bronchial responsiveness in healthy subjects exposed to organic dust. Eur Respir J. 2002;20(2):426-31.

66. Von Essen S, Romberger D. The respiratory inflammatory response to the swine confinement building environment: the adaptation to respiratory exposures in the chronically exposed worker. J Agric Saf Health. 2003;9(3):185-96.

67. Sahlander K, Larsson K, Palmberg L. Daily exposure to dust alters innate immunity. PLoS ONE. 2012;7(2):e31646.

68. May S, Romberger DJ, Poole JA. Respiratory health effects of large animal farming environments. J Toxicol Environ Health B Crit Rev. 2012;15(8):524-41.

69. LeVan TD, Romberger DJ, Siahpush M, Grimm BL, Ramos AK, Johansson $\mathrm{PL}$, et al. Relationship of systemic IL-10 levels with proinflammatory cytokine responsiveness and lung function in agriculture workers. Respir Res. 2018;19(1):166.

70. Fan H, Cook JA. Molecular mechanisms of endotoxin tolerance. J Endotoxin Res. 2004;10(2):71-84.

71. Biswas SK, Lopez-Collazo E. Endotoxin tolerance: new mechanisms, molecules and clinical significance. Trends Immunol. 2009;30(10):475-87.

72. Liu D, Cao S, Zhou Y, Xiong Y. Recent advances in endotoxin tolerance. J Cell Biochem. 2019;120(1):56-70.

73. Radon K, Goldberg M, Becklake M. Healthy worker effect in cohort studies on chronic bronchitis. Scand J Work Environ Health. 2002;28(5):328-32.

74. Rinsky JL, Richardson DB, Kreiss K, Nylander-French L, Beane Freeman LE, London SJ, et al. Animal production, insecticide use and selfreported symptoms and diagnoses of COPD, including chronic bronchitis, in the Agricultural Health Study. Environ Int. 2019;127:764-72.

75. Spierenburg EA, Smit LA, Heederik D, Robbe P, Hylkema MN, Wouters IM. Healthy worker survivor analysis in an occupational cohort study of Dutch agricultural workers. Int Arch Occup Environ Health. 2015:88(8):1165-73.

76. Sigsgaard T, Hjort C, Omland, Miller MR, Pedersen OF. Respiratory health and allergy among young farmers and non-farming rural males. J Agromed. 1997;4:63-78.

77. Riedler J, Braun-Fahrlander C, Eder W, Schreuer M, Waser M, Maisch S, et al. Exposure to farming in early life and development of asthma and allergy: a cross-sectional survey. Lancet. 2001;358(9288):1129-33.

78. Braun-Fahrlander C, Riedler J, Herz U, Eder W, Waser M, Grize L, et al. Environmental exposure to endotoxin and its relation to asthma in school-age children. N Engl J Med. 2002;347(12):869-77.

79. Braun-Fahrlander C, Gassner M, Grize L, Neu U, Sennhauser FH, Varonier $\mathrm{HS}$, et al. Prevalence of hay fever and allergic sensitization in farmer's children and their peers living in the same rural community. SCARPOL team. Swiss Study on Childhood Allergy and Respiratory Symptoms with Respect to Air Pollution. Clin Exp Allergy. 1999;29(1):28-34.

80. Von Ehrenstein OS, Von Mutius E, Illi S, Baumann L, Bohm O, von Kries R. Reduced risk of hay fever and asthma among children of farmers. Clin Exp Allergy. 2000;30(2):187-93.

81. Genuneit J. Exposure to farming environments in childhood and asthma and wheeze in rural populations: a systematic review with meta-analysis. Pediatr Allergy Immunol. 2012;23(6):509-18.

82. Elholm G, Linneberg A, Husemoen LL, Omland O, Gronager PM, Sigsgaard T, et al. The Danish urban-rural gradient of allergic sensitization and disease in adults. Clin Exp Allergy. 2016;46(1):103-11.
83. von Mutius E, Vercelli D. Farm living: effects on childhood asthma and allergy. Nat Rev Immunol. 2010;10(12):861-8.

84. Lluis A, Schaub B. Lesson from the farm environment. Curr Opin Allergy Clin Immunol. 2012;12(2):158-63.

85. Kilpelainen M, Terho EO, Helenius $\mathrm{H}$, Koskenvuo M. Farm environment in childhood prevents the development of allergies. Clin Exp Allergy. 2000;30(2):201-8.

86. Ernst P, Cormier Y. Relative scarcity of asthma and atopy among rural adolescents raised on a farm. Am J Respir Crit Care Med. 2000;161(5):1563-6.

87. Leynaert B, Neukirch C, Jarvis D, Chinn S, Burney P, Neukirch F, et al. Does living on a farm during childhood protect against asthma, allergic rhinitis, and atopy in adulthood? Am J Respir Crit Care Med. 2001;164(10 Pt 1):1829-34.

88. Portengen L, Sigsgaard T, Omland O, Hjort C, Heederik D, Doekes G. Low prevalence of atopy in young Danish farmers and farming students born and raised on a farm. Clin Exp Allergy. 2002;32(2):247-53.

89. Douwes J, Travier N, Huang K, Cheng S, McKenzie J, Le Gros G, et al. Lifelong farm exposure may strongly reduce the risk of asthma in adults. Allergy. 2007;62(10):1158-65.

90. Stein MM, Hrusch CL, Gozdz J, Igartua C, PivnioukV, Murray SE, et al. Innate immunity and asthma risk in amish and hutterite farm children. N Engl J Med. 2016;375(5):411-21.

91. Chen Y, Rennie D, Cormier Y, McDuffie H, Pahwa P, Dosman J. Reduced risk of atopic sensitization among farmers: the Humboldt study. Int Arch Allergy Immunol. 2007;144(4):338-42.

92. Lampi J, Canoy D, Jarvis D, Hartikainen AL, Keski-Nisula L, Jarvelin MR, et al. Farming environment and prevalence of atopy at age 31: prospective birth cohort study in Finland. Clin Exp Allergy. 2011;41(7):987-93.

93. Galli L, Facchetti S, Raffetti E, Donato F, D'Anna M. Respiratory diseases and allergic sensitization in swine breeders: a population-based crosssectional study. Ann Allergy Asthma Immunol. 2015;115(5):402-7.

94. Rennie DC, Karunanayake CP, Chen Y, Lawson JA, Hagel L, Senthilselvan $A$, et al. Early farm residency and prevalence of asthma and hay fever in adults. J Asthma. 2016;53(1):2-10.

95. Blackley C. Experimental researches on the causes and nature of catarrhus æstivus (hay-fever or hay-asthma). London: Bailliere Tindall and Cox; 1873. p. 202

96. Douwes J, Brooks C, Pearce N. Protective effects of farming on allergies and asthma: have we learnt anything since 1873? Expert Rev Clin Immunol. 2009;5(3):213-9.

97. Alfven T, Braun-Fahrlander C, Brunekreef B, von Mutius E, Riedler J Scheynius A, et al. Allergic diseases and atopic sensitization in children related to farming and anthroposophic lifestyle - the PARSIFAL study. Allergy. 2006;61(4):414-21.

98. Schram-Bijkerk D, Doekes G, Boeve M, Douwes J, Riedler J, Ublagger E, et al. Exposure to microbial components and allergens in population studies: a comparison of two house dust collection methods applied by participants and fieldworkers. Indoor Air. 2006;16(6):414-25.

99. Schram-Bijkerk D, Doekes G, Douwes J, Boeve M, Riedler J, Ublagger E, et al. Bacterial and fungal agents in house dust and wheeze in children: the PARSIFAL study. Clin Exp Allergy. 2005;35(10):1272-8.

100. Smit LA, Zuurbier M, Doekes G, Wouters IM, Heederik D, Douwes J. Hay fever and asthma symptoms in conventional and organic farmers in The Netherlands. Occup Environ Med. 2007;64(2):101-7.

101. Smit LA, Heederik D, Doekes G, Lammers JW, Wouters IM. Occupational endotoxin exposure reduces the risk of atopic sensitization but increases the risk of bronchial hyperresponsiveness. Int Arch Allergy Immunol. 2010;152(2):151-8.

102. Radon K, Ehrenstein V, Praml G, Nowak D. Childhood visits to animal buildings and atopic diseases in adulthood: an age-dependent relationship. Am J Ind Med. 2004:46(4):349-56.

103. Radon K, Schulze A, Nowak D. Inverse association between farm animal contact and respiratory allergies in adulthood: protection, underreporting or selection? Allergy. 2006;61(4):443-6.

104. Eduard W, Douwes J, Omenaas E, Heederik D. Do farming exposures cause or prevent asthma? Results from a study of adult Norwegian farmers. Thorax. 2004;59(5):381-6.

105. Casas L, Tischer C, Taubel M. Pediatric Asthma and the Indoor Microbial Environment. Curr Environ Health Rep. 2016;3(3):238-49. 
106. Douwes J, Thorne P, Pearce N, Heederik D. Bioaerosol health effects and exposure assessment: progress and prospects. Ann Occup Hyg. 2003:47(3):187-200.

107. Duquenne P, Marchand G, Duchaine C. Measurement of endotoxins in bioaerosols at workplace: a critical review of literature and a standardization issue. Ann Occup Hyg. 2013;57(2):137-72.

108. Ghosh B, Lal H, Srivastava A. Review of bioaerosols in indoor environment with special reference to sampling, analysis and control mechanisms. Environ Int. 2015;85:254-72.

109. Mensah-Attipoe J, Taubel M, Hernandez M, Pitkaranta M, Reponen T. An emerging paradox: toward a better understanding of the potential benefits and adversity of microbe exposures in the indoor environment. Indoor Air. 2017;27(1):3-5.

110. Raulf M, Buters J, Chapman M, Cecchi L, de Blay F, Doekes G, et al. Monitoring of occupational and environmental aeroallergens-EAACI Position Paper. Allergy. 2014;69:1280-99.

111. Basinas I, Cronin G, Hogan V, Sigsgaard T, Hayes J, Coggins AM. Exposure to inhalable dust, endotoxin, and total volatile organic carbons on dairy farms using manual and automated feeding systems. Ann Work Expo Health. 2017;61(3):344-55.

112. Eduard W. Fungal spores: a critical review of the toxicological and epidemiological evidence as a basis for occupational exposure limit setting. Crit Rev Toxicol. 2009;39(10):799-864.

113. Viegas S, Viegas C, Oppliger A. occupational exposure to mycotoxins: current knowledge and prospects. Ann Work Expo Health. 2018;62(8):923-41.

114. Samadi S, Heederik DJJ, Zahradnik E, Rietbroek NNJ, van Eerdenburg $\mathrm{F}$, Sander I, et al. Bovine allergens in a ruminant clinic and dairy barns: exposure levels, determinants, and variability. Ann Work Expo Health. 2018;62(6):663-73.

115. Virtanen T, Vilhunen P, Husman K, Happonen P, Mantyjarvi R. Level of airborne bovine epithelial antigen in Finnish cowsheds. Int Arch Occup Environ Health. 1988;60(5):355-60.

116. Samadi S, Wouters IM, Houben R, Jamshidifard AR, Van Eerdenburg F, Heederik DJ. Exposure to inhalable dust, endotoxins, beta( $\rightarrow 3)$-glucans, and airborne microorganisms in horse stables. Ann Occup Hyg. 2009;53(6):595-603.

117. Elfman L, Brannstrom J, Smedje G. Detection of horse allergen around a stable. Int Arch Allergy Immunol. 2008;145(4):269-76.

118. Emenius G, Larsson PH, Wickman M, Harfast B. Dispersion of horse allergen in the ambient air, detected with sandwich ELISA. Allergy. 2001;56(8):771-4

119. Davidson ME, Schaeffer J, Clark ML, Magzamen S, Brooks EJ, Keefe TJ, et al. Personal exposure of dairy workers to dust, endotoxin, muramic acid, ergosterol, and ammonia on large-scale dairies in the high plains Western United States. J Occup Environ Hyg. 2018;15(3):182-93.

120. Skaug MA, Eduard W, Stormer FC. Ochratoxin A in airborne dust and fungal conidia. Mycopathologia. 2001;151(2):93-8.

121. Sabino R, Faisca VM, Carolino E, Verissimo C, Viegas C. Occupational exposure to Aspergillus by swine and poultry farm workers in Portugal. J Toxicol Environ Health A. 2012;75(22-23):1381-91.

122. Viegas S, Assuncao R, Martins C, Nunes C, Osteresch B, Twaruzek M, et al. Occupational exposure to mycotoxins in swine production: environmental and biological monitoring approaches. Toxins. 2019;11(2):78.

123. Thilsing T, Madsen AM, Basinas I, Schlunssen V, Tendal K, Baelum J. Dust, endotoxin, fungi, and bacteria exposure as determined by work task, season, and type of plant in a flower greenhouse. Ann Occup Hyg 2015:59(2):142-57.

124. Preller L, Heederik D, Kromhout H, Boleij JS, Tielen MJ. Determinants of dust and endotoxin exposure of pig farmers: development of a control strategy using empirical modelling. Ann Occup Hyg. 1995;39(5):545-57.

125. Pavilonis BT, Anthony TR, O'Shaughnessy PT, Humann MJ, Merchant JA, Moore G, et al. Indoor and outdoor particulate matter and endotoxin concentrations in an intensely agricultural county. J Expo Sci Environ Epidemiol. 2013;23(3):299-305.

126. O'Shaughnessy PT, Donham KJ, Peters TM, Taylor C, Altmaier R, Kelly KM A task-specific assessment of Swine worker exposure to airborne dust. J Occup Environ Hyg. 2010;7(1):7-13.

127. O'Shaughnessy PT, Lo J, Golla V, Nakatsu J, Tillery MI, Reynolds S. Correction of sampler-to-sampler comparisons based on aerosol size distribution. J Occup Environ Hyg. 2007;4(4):237-45.
128. Basinas I, Sigsgaard T, Erlandsen M, Andersen NT, Takai H, Heederik D, et al. Exposure-affecting factors of dairy farmers' exposure to inhalable dust and endotoxin. Ann Occup Hyg. 2014;58:707-23.

129. Basinas I, Sigsgaard T, Heederik D, Takai H, Omland O, Andersen NT, et al. Exposure to inhalable dust and endotoxin among Danish livestock farmers: results from the SUS cohort study. J Environ Monit. 2012;14(2):604-14.

130. Garcia J, Bennett DH, Tancredi D, Schenker MB, Mitchell D, Reynolds SJ, et al. Occupational exposure to particulate matter and endotoxin for California dairy workers. Int J Hyg Environ Health. 2013;216(1):56-62.

131. Halstensen AS, Nordby KC, Wouters IM, Eduard W. Determinants of microbial exposure in grain farming. Ann Occup Hyg. 2007;51(7):581-92.

132. Vinzents $\mathrm{P}$, Nielsen $\mathrm{BH}$. Variations in exposures to dust and endotoxin in Danish piggeries. Am Ind Hyg Assoc J. 1992;53(4):237-41.

133. Reynolds SJ, Parker D, Vesley D, Janni K, Mc Jilton C. Occupational exposure to organic dusts and gases in the Turkey growing industry. Appl Occup Environ Hyg. 1994;9(7):493-502.

134. Golbabaei F, Islami F. Evaluation of workers' exposure to dust, ammonia and endotoxin in poultry industries at the province of Isfahan, Iran. Ind Health. 2000;38(1):41-6.

135. Samadi S, van Eerdenburg FJ, Jamshidifard AR, Otten GP, Droppert $M$, Heederik DJ, et al. The influence of bedding materials on bio-aerosol exposure in dairy barns. J Expo Sci Environ Epidemiol. 2012;22(4):361-8.

136. Kim J, Arrandale VH, Kudla I, Mardell K, Lougheed D, Holness DL. Educational intervention among farmers in a community health care setting. Occup Med. 2012;62(6):458-61.

137. Mazurek JM, White GE, Rodman C, Schleiff PL. Farm workrelated asthma among US primary farm operators. J Agromed. 2015;20(1):31-42.

138. Szeszenia-Dabrowska N, Swiatkowska B, Wilczynska U. Occupational diseases among farmers in Poland. Med Pr. 2016;67(2):163-71.

139. Basinas I, Sigsgaard T, Bonlokke JH, Andersen NT, Omland O, Kromhout $\mathrm{H}$, et al. Feedback on measured dust concentrations reduces exposure levels among farmers. Ann Occup Hyg. 2016;60(7):812-24.

140. Howie NM. Regulation of paraprofessionals. Vet Rec. 2005;156(3):95.

141. Hoppin JA, Umbach DM, London SJ, Alavanja MC, Sandler DP. Animal production and wheeze in the Agricultural Health Study: interactions with atopy, asthma, and smoking. Occup Environ Med. 2003;60(8):e3.

142. Mazurek JM, Henneberger PK. Lifetime allergic rhinitis prevalence among US primary farm operators: findings from the 2011 Farm and Ranch Safety survey. Int Arch Occup Environ Health. 2017;90(6):507-15.

143. Elfman L, Riihimaki M, Pringle J, Walinder R. Influence of horse stable environment on human airways. J Occup Med Toxicol. 2009;4:10.

144. Tual S, Clin B, Leveque-Morlais N, Raherison C, Baldi I, Lebailly P. Agricultural exposures and chronic bronchitis: findings from the AGRICAN (AGRIculture and CANcer) cohort. Ann Epidemiol. 2013;23(9):539-45.

145. Viegas S, Mateus V, Almeida-Silva M, Carolino E, Viegas C. Occupational exposure to particulate matter and respiratory symptoms in Portuguese swine barn workers. J Toxicol Environ Health A. 2013;76(17):1007-14.

146. Rodriquez EJ, Stoecklin-Marois MT, Bennett DH, Tancredi DJ, Schenker MB. Agricultural work exposures and pulmonary function among hired farm workers in California (the MICASA study). J Agromed. 2014;19(4):427-36.

147. Mitchell DC, Armitage TL, Schenker MB, Bennett DH, Tancredi DJ, Langer CE, et al. Particulate matter, endotoxin, and worker respiratory health on large Californian dairies. J Occup Environ Med. 2015;57(1):79-87.

148. Nonnenmann MW, de Gimeno Ruiz Porras D, Levin J, Douphrate D, Boggaram V, Schaffer J, et al. Pulmonary function and airway inflammation among dairy parlor workers after exposure to inhalable aerosols. Am J Ind Med. 2017;60(3):255-63.

149. Varraso R, Oryszczyn MP, Mathieu N, Le Moual N, Boutron-Ruault MC, Clavel-Chapelon F, et al. Farming in childhood, diet in adulthood and asthma history. Eur Respir J. 2012;39(1):67-75.

150. Koskela HO, Happonen KK, Remes ST, Pekkanen J. Effect of farming environment on sensitisation to allergens continues after childhood. Occup Environ Med. 2005;62(9):607-11. 
151. Portengen L, Preller L, Tielen M, Doekes G, Heederik D. Endotoxin exposure and atopic sensitization in adult pig farmers. J Allergy Clin Immunol. 2005;115(4):797-802.

152. Schulze A, van Strien RT, Praml G, Nowak D, Radon K. Characterisation of asthma among adults with and without childhood farm contact. Eur Respir J. 2007;29(6):1169-73.

153. Eriksson J, Ekerljung L, Lotvall J, Pullerits T, Wennergren G, Ronmark E, et al. Growing up on a farm leads to lifelong protection against allergic rhinitis. Allergy. 2010;65(11):1397-403.

154. Rennie DC, Lawson JA, Karunanayake CP, Pahwa P, Chen Y, Chu L, et al. Farm exposure and atopy in men and women: the Saskatchewan Rural Health Study. J Agromedicine. 2015;20(3):302-9.

155. Bonlokke JH, Meriaux A, Duchaine C, Godbout S, Cormier Y. Seasonal variations in work-related health effects in swine farm workers. Ann Agric Environ Med. 2009;16(1):43-52.

156. Radon K, Danuser B, Iversen M, Monso E, Weber C, Hartung J, et al. Air contaminants in different European farming environments. Ann Agric Environ Med. 2002;9(1):41-8.

157. Szadkowska-Stanczyk I, Brodka K, Buczynska A, Cyprowski M, Kozajda A, Sowiak M. Exposure to bioaerosols among CAFO workers (swine feeding). Med Pr. 2010;61(3):257-69.

158. Sander I, Fleischer C, Borowitzki G, Bruning T, Raulf-Heimsoth M. Development of a two-site enzyme immunoassay based on monoclonal antibodies to measure airborne exposure to (1->3)-beta-D-glucan. J Immunol Methods. 2008:337(1):55-62.

159. Burch JB, Svendsen E, Siegel PD, Wagner SE, von Essen S, Keefe T, et al. Endotoxin exposure and inflammation markers among agricultural workers in Colorado and Nebraska. J Toxicol Environ Health A. 2010;73(1):5-22

160. Firth $H$, Herbison P, Mc Bride D. Dust and noise exposures among farmers in Southland, New Zealand. Int J Environ Health Res. 2006;16(2):155-61.

161. Saito R, Cranmer BK, Tessari JD, Larsson L, Mehaffy JM, Keefe TJ, et al. Recombinant factor C ( $\mathrm{FCC}$ ) assay and gas chromatography/mass spectrometry (GC/MS) analysis of endotoxin variability in four agricultural dusts. Ann Occup Hyg. 2009;53(7):713-22.

162. Spaan S, Wouters IM, Oosting I, Doekes G, Heederik D. Exposure to inhalable dust and endotoxins in agricultural industries. J Environ Monit. 2006;8(1):63-72.
163. Donham KJ, Cumro D, Reynolds S. Synergistic effects of dust and ammonia on the occupational health effects of poultry production workers. J Agromed. 2002;8(2):57-76.

164. Senthilselvan A, Beach J, Feddes J, Cherry N, Wenger I. A prospective evaluation of air quality and workers' health in broiler and layer operations. Occup Environ Med. 2011;68(2):102-7.

165. Arteaga V, Mitchell D, Armitage T, Tancredi D, Schenker M, Mitloehner F. Cage versus noncage laying-hen housings: respiratory exposures. J Agromed. 2015;20(3):245-55.

166. Chang CW, Chung H, Huang CF, Su HJ. Exposure assessment to airborne endotoxin, dust, ammonia, hydrogen sulfide and carbon dioxide in open style swine houses. Ann Occup Hyg. 2001;45(6):457-65.

167. Mc Donnell PE, Coggins MA, Hogan VJ, Fleming GT. Exposure assessment of airborne contaminants in the indoor environment of Irish swine farms. Ann Agric Environ Med. 2008;15(2):323-6.

168. Reynolds SJ, Nonnenmann MW, Basinas I, Davidson M, Elfman L, Gordon J, et al. Systematic review of respiratory health among dairy workers. J Agromed. 2013;18(3):219-43.

169. Kim KY, Ko HJ, Kim YS, Kim CN. Assessment of Korean farmer's exposure level to dust in pig buildings. Ann Agric Environ Med. 2008;15(1):51-8.

170. Choudhry AH, Reynolds SJ, Mehaffy J, Douphrate DI, Gilmore K, Levin $J$, et al. Evaluation of parlor cleaning as an intervention for decreased occupational exposure to dust and endotoxin among dairy parlor workers-a pilot study. J Occup Environ Hyg. 2012;9(7):D136-40.

171. Kirychuk SP, Dosman JA, Reynolds SJ, Willson P, Senthilselvan A, Feddes $J$, et al. Total dust and endotoxin in poultry operations: comparison between cage and floor housing and respiratory effects in workers. J Occup Environ Med. 2006:48(7):741-8.

172. Whyte RT. Occupational exposure of poultry stockmen in current barn systems for egg production in the United Kingdom. Br Poult Sci. 2002;43(3):364-73.

\section{Publisher's Note}

Springer Nature remains neutral with regard to jurisdictional claims in published maps and institutional affiliations.
Ready to submit your research? Choose BMC and benefit from:

- fast, convenient online submission

- thorough peer review by experienced researchers in your field

- rapid publication on acceptance

- support for research data, including large and complex data types

- gold Open Access which fosters wider collaboration and increased citations

- maximum visibility for your research: over $100 \mathrm{M}$ website views per year

At BMC, research is always in progress.

Learn more biomedcentral.com/submissions 